\title{
Kentsel teknik altyapı tesislerine yönelik uluslararası coğrafi veri modellerinin analizi
}

\author{
Azer İlgar ${ }^{1}(\mathbb{D})$, Volkan Çağdaş²(D) \\ ${ }^{1}$ Hacettepe Üniversitesi, Beytepe Kampüsü, Mühendislik Fakültesi, Geomatik Mühendisliği Bölümü, Çankaya, Ankara, Türkiye. \\ ${ }^{2}$ Yıldız Teknik Üniversitesi, Davutpaşa Kampüsü, Inşaat Fakültesi, Harita Mühendisliği Bölümü, Esenler, İstanbul, Türkiye.
}

Öz: Teknik altyapı tesisleri, elektrik, su, doğalgaz, telekomünikasyon gibi hizmetleri ileten fiziksel nesneler ile bu nesnelerin oluşturduğu şebekeleri ifade eder. Günümüzde özellikle kentlerdeki nüfus artışı ile yer altı kullanımı yoğunlaşmakta; aynı zamanda özelleştirme süreçleriyle birlikte teknik altyapı sektöründe dağınık ve parçalı bir yapı meydana gelmektedir. Teknik altyapı tesislerine ait coğrafi veriler genellikle ilgili kuruluşlar tarafindan işletme veya varlık yönetimi amacıyla çeşitli format ve yapılarda tutulmaktadır. Tesislerin planlama, inşa, bakım ve onarım süreçleri ile acil durum müdahaleleri, afet planlama ve müdahale ile akıllı kent programları gibi uygulamalar, tüm kullanıcıların güncel konumsal veriye kısa sürede erişmelerini zorunlu kılar. Bu nedenle, teknik altyapı kuruluşlarl, yerel yönetimler ve diğer kamu kurumları arasında coğrafi veri değişiminin etkinleştirilmesi gerekir. Birçok ulusal ve uluslararası standardizasyon kuruluşu, coğrafi veri değişimi gerektiren farklı kullanım durumlarına yönelik gereksinimlere odaklanan veri (değişim) modelleri geliş̧irmekte ve/veya veri değişim yöntemleri belirlemektedir. Bu çalışma, teknik altyapı tesislerine ait coğrafi verilerin paylaşım süreçlerinin iyileştirilmesine olanak veren uluslararası veri standartlarl ve modellerini irdelemektedir. Uluslararast veri standartları ve modellerinin içerik, kapsam, işlevsellik ve coğrafi temsil yeteneklerinin, odaklandıkları kullanım durumlarına göre farklılık gösterdiği belirlenmiş; tüm gereksinimlere yanıt verecek bir coğrafi veri modelinin bulunmadĭ̆

Anahtar Sözcükler: Coğrafi veri standartları, Teknik altyapı tesisleri, Coğrafi veri değişimi, Coğrafi veri modelleri

\section{An analysis of international geospatial information models for urban utility networks}

Abstract: Utility networks consist of physical constructions which transport utility service products such as power, water, gas and telecommunication. The pressure of urban population growth increases the density of urban underground areas, moreover, privatization of utilities increases decentralization and fragmentation in the utility sector. Geographic information related to utility networks are mainly held in various formats by utility organizations for operation and asset management activities. Integration and information exchange of utility data are required for numerous activities, namely design, construction and repair of utility networks, disaster planning, emergency response. The differences in data models and information systems limit the ability of integration of different utility data, as well as information exchange among relevant parties such as utility companies, local authorities and other public bodies. Several national and international standardization organizations develop data models and/or data exchange methods that focus on the needs for different use cases which require geospatial data exchange. This paper examines international data models for sharing and exchange of utility network data. It is emphasized that there is no international data model addressing the needs of all use cases, while the models' content, scope, functionality, and geographic representation capabilities depend on the use cases they focus on.

Keywords: Geospatial data standards, Utility networks, Geospatial information exchange, Geospatial information models 


\section{Giriş}

Teknik altyapı tesisleri, kent yaşamının işleyişi için gereksinim duyulan elektrik, temiz ve atık su, doğal gaz ve haberleşme gibi hizmetlerle ilişkili ürünlerin taşınması ve kontrol edilmesi için kurulmuş fiziksel yapılardır. Bir teknik altyapı şebekesi, bir teknik altyapı hizmetiyle ilişkili ürünü, kaynaktan alıcıya, birbirlerine bağlı kablo, boru, pompa, vana gibi tesisler aracılı̆̆ıla ulaştırır. Teknik altyapı tesisleri maliyet, zemin durumu, arazi kullanım durumu, güvenlik vb. gibi etmenlere bağlı olarak gömülü, yer üstünde veya zeminde kurulmuş olabilir. Genellikle kablo ve borular yer yüzeyindeki menholler ile erişilebilecek biçimde yolların altında gömülü olarak tesis edilmektedir. Teknik altyapı tesislerine ait coğrafi veriler, tesislerin malzeme, büyüklük, kapasite gibi fiziksel özellikleri ile (yatay ve bazen düşey) konumlarını içerir. Bu veriler, teknik altyapı kuruluşları tarafından genellikle işletme veya varlık yönetimi amacıyla üretilmekte ve yönetilmektedir. Teknik altyapı piyasasında özelleştirme ve ayrıştırma uygulamaları, faaliyet gösteren kuruluş sayısını önemli ölçüde artırmıştır. Dahası, bir teknik altyapı hizmetine ait toplama, iletim, dağııım gibi hizmetlerin her biri farklı kuruluşlar tarafından sunulabilmektedir. Ayrıca, tesislerin sahipleri, kullanıcıları ve işletmecileri birbirlerinden farklı olabilir. Bu kuruluşların her biri farklı şema ve formatta coğrafi veri üretmektedir; diğer bir ifadeyle coğrafi veriler sözdizimsel, şematik ve anlamsal bakımdan heterojen bir yapıdadır (Beck, Fu, Cohn, Bennett, \& Stell, 2008). Bu makale, teknik altyapı tesislerine ait heterojen ve dağınık yapıda bulunan coğrafi verilerin çeşitli uygulamalarda bütüncül biçimde kullanımı için geliştirilen coğrafi veri modelleme yaklaşım ve uygulamalarına odaklanmaktadır.

Farklı sektörlere ait teknik altyapı tesisleri, birbirlerine bağıml, bir başka ifadeyle birbirleriyle konumsal, fiziksel ve işlevsel bakımdan ilişkili bulunan tesislerden oluşmaktadır (Islam \& Moselhi, 2012; Rinaldi, Peerenboom, \& Kelly, 2001; Yang, Ng, Xu, \& Skitmore, 2018). Bu nedenle, farklı kuruluşlara ait teknik altyapı tesislerine ilişkin coğrafi verilere gereksinim duyan kimi faaliyetler coğrafi verilerin bütünleştirilmesini, ilgili kuruluşlar arasında veri değişimini ve paylaşımını zorunlu kılar. Ancak kuruluşların bu verileri gizlilik, güvenlik, rekabet vb. nedenlerle gizli tutma eğiliminde olmaları, verilerin şematik ve anlamsal bakımdan heterojen yapıda bulunması, coğrafi verilerin farklı uygulamalarda kullanılmak üzere paylaşılmasını ve bütünleştirilmesini güçleştirmektedir (olde Scholtenhuis, Hartmann, \& Dorée, 2016).

Açık Coğrafi Konsorsiyum (Open Geospatial Consortium, OGC) Yaratıcılık Programı (Innovation Program) kapsamında geliştirilmekte olan Yeraltı Yapıları Pilot Projesi (Underground Infrastructure Pilot) ile ilgili "Yeraltı Altyapıları Kapsam Çalışması Mühendislik Raporu", teknik altyapı tesislerine ait coğrafi veri değişimi ve paylaşımı gerektiren kullanım durumlarını; (1) rutin sokak kazıları, (2) acil durum müdahaleleri, (3) bakım programları, (4) büyük ölçekli inşaat projeleri, (5) afet planlama ve müdahale, (6) akıllı kent programları olarak belirlemiştir (Lieberman \& Ryan, 2017).

Kent içlerinde yolların altını yoğun bir biçimde kullanan tesislerin kullanım ömürlerini doldurması, hasar görmesi veya yenilenmesi nedenleriyle yapılacak kazı ve inşaat çalışmalarının kent idareleri ile koordineli biçimde yürütülmesi, kazı ve inşaat süreçlerinde güvenliğin sağlanmasını ve ekonomik kayıpların önlenmesini sağlar (Talmaki, Kamat, \& Cai, 2013). Altyapı kuruluşları ile yerel yönetimler, tekrarlı kazı çalışmaları ile birlikte olası kaza ve maddi hasarları önlemek için çalışma yapılan bölgede mevcut ve planlanan tesislere ait verilere gereksinim duyarlar. Bu verilerin doğru ve hızlı bir şekilde paylaşımı, mevcut tesislerin onarım, deplase edilme veya yeni tesislerin kurulma süreçlerindeki planlama, projelendirme ve inşaat faaliyetlerinin koordineli bir biçimde yürütülmesini sağlar. Ayrıca, bu verilerin varlığı inşaat çalışmaları ya da afetler nedeniyle tesislerin hasar görmesi sonucunda etkilenecek kullanıcıların, bölgelerin ve diğer tesislerin tespit edilmesi, acil müdahaleler ile alınması gereken diğer önlemlerin belirlenmesi için coğrafi analizlerin yapılmasına olanak verir (Becker, Bartels, Hahne, Hempel, \& Lieb, 2012). 
$\mathrm{Bu}$ makalede, teknik altyapı tesislerine ilişskin coğrafi verilerin farklı uygulamalar için kullanımı, taraflar arasında paylaşımı ve değişimi için geliştirilen (standart) coğrafi veri modelleri incelenmektedir. Standart bir altyapı veri modeli, farklı sektörlere ait altyapı tesislerinin coğrafi ve coğrafi olmayan özellikleri ile birbirleri arasındaki ilişkileri içeren bir şema sunarak verilerin değişimi ve temsilinde anlamsal ve yapısal bir birlik sağlar. Teknik altyapı verilerinin standartlaştırılması, farklı sistemler arasında birlikte çalışabilirliği geliştirir; kullanıcılara mevcut verileri yeniden kullanma, iş süreçlerini koordine etme ve hayati bilgileri verimli ve etkili bir şekilde paylaşma olanağı sağlar.

Coğrafi veri modellerinin içeriği, uygulama alanına veya amaca göre farklılık gösterir. Örneğin, rutin sokak kazıları için tesislerin 3 boyutlu konumları ile fiziksel özellikleri; bakım programları için ise bu özelliklere ek olarak kullanım ömürleri, üretim ve yerleştirme ya da devreye alınma, bakım, onarım zamanları gibi zamansal özellikler gereklidir. Acil durum müdahaleleri, afet planlama ile akıllı kent programları (Al-Hader, Rodzi, Sharif, \& Ahmad, 2009; Marzouk \& Othman, 2020), tüm teknik altyapı tesislerinin karşılıklı bağımlılıklarını da kapsayan bütüncül ve topolojik ağ yapısına sahip bir modelleme yaklaşımına gereksinim duyar (Becker vd., 2012). Büyük ölçekli inşaat mühendisliği projelerinde ise bölgedeki teknik altyap1 tesislerine ait kapasite, fiziksel durum gibi bilgiler ile hassas (yatay ve düşey) konumsal veriler gereklidir (Gale \& Hammerschmidt, 2015; Jung, 2012; Sterling vd., 2009). Kent ve çevre planlama, afet yönetim ve acil durum müdahale simülasyonları, ulaştırma, teknik altyapı tesislerinin planlanması ve inşası, işletmesi ve bakımı gibi birçok faaliyet teknik altyapı tesislerinin hem yatay hem düşey konum bilgilerine gereksinim duyar.

İzleyen bölümde uluslararası standardizasyon kuruluşları tarafından yayımlanmış ve halen geliştirilmekte olan standart veri modelleri ile bu modellerin literatürde öne çıkan uygulamaları özetlenmiştir. Ardından incelenen veri modellerinin içerikleri, geometrik temsil yetenekleri ve işlevsellikleri karşılaştırılmış, yapılan değerlendirmelerle makale sonlandırılmıştır.

\section{Standart Veri Modelleri}

\subsection{INSPIRE Altyapı Ağları Profili}

Avrupa Birliği coğrafi veri altyapısının oluşturulmasını amaçlayan INSPIRE girişimi, çevreyle ilişkili coğrafi verilerin hem ulusal düzeyde hem de Avrupa düzeyinde paylaşımının etkinleştirilmesini hedeflemektedir. Bu kapsamda, çevresel politika ve uygulamalar için gereksinim duyulan coğrafi veriler, genel kavramsal model (General Conceptual Model) ve 34 veri teması ile tanımlanmıştır. $\mathrm{Bu}$ temalara ait coğrafi verilerin tanımlanmış veri spesifikasyonları ile uyumlandırılması hedeflenmiştir. Genel kavramsal model, birden fazla temada kullanılan ortak veri tipini ve modellerini tanımlamaktadır.

Teknik altyapı tesislerine ilişkin tanımlamalar Altyapı ve Kamusal Hizmetler (Utility and Governmental Services) veri temasında yer almaktadır. INSPIRE Teknik Altyapı Ağları (INSPIRE Utility Networks, INSPIRE-UN) veri şemasının amacı, farklı kuruluşların yönettiği değişken yapıda ve düzeyde bulunan veri ve veri modellerini uyumlu hale getirmektir (INSPIRE, 2013). Böylelikle teknik altyapı kuruluşları arasındaki verinin yeniden kullanımı etkinleşecektir.

INSPIRE-UN, genel kavramsal modelde tanımlanmış Genel Ă̆ Modelinin (Generic Network Model) bir profilidir. Teknik altyapı ağları profili, teknik altyapı ağlarının ve tesislerinin genel ağ modelinde sunulan yaklaşımla topolojik bir yapıda temsilini sağlar. Burada, birden fazla teknik altyapı şebekesinde yer alan ortak tesislere ve 6 farklı sektöre özgü tesislere ait uygulama şemaları yer almaktadır.

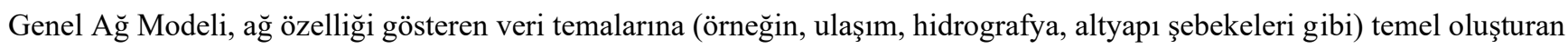
bir uygulama şemasıdır (Şekil 1a). Burada esas olarak ağı oluşturan nokta ve çizgi geometrisine sahip nesneler arasındaki 
ilişkiler tanımlanmaktadır. Bir doğrusal nesne, başındaki ve sonundaki düğüm noktalarıyla ve yönüyle birlikte

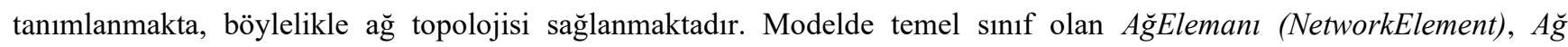
(Network) sınıfını oluşturan elemanları temsil eder. Ağlardaki doğrusal nesneler, Hat (Link), HatSeti (LinkSet) ve HatDizisi (LinkSequence) sınıflarıyla; nokta özelliğine sahip nesneler ise DügüumNoktası (Node) sınıfı ile temsil edilmektedir.

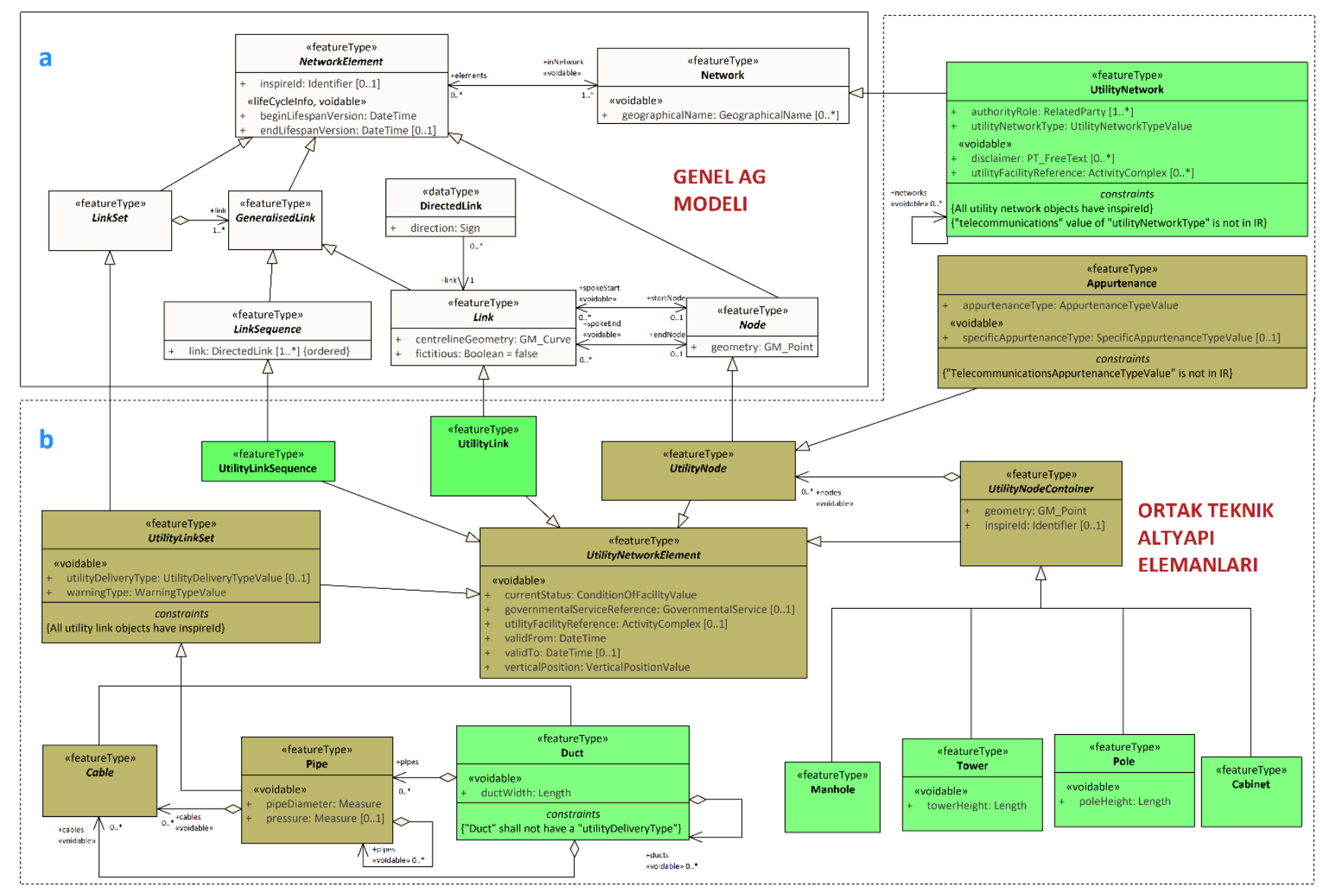

Şekil 1: a) INSPIRE genel ağ modeli, b) Teknik altyapı ağları profilinde ortak teknik altyapı tesisleri

Teknik altyapı ağları profilinin oluşturulması için genel ağ modelindeki; A $\breve{g}$, HatSeti ve DüğümNoktası sınıfları genişletilerek sırasıyla TeknikAltyapıAğı (UtilityNetwork), TeknikAltyapıHatDizisi (UtilityLinkSet) ve TeknikAltyapıDüğ̈̈mNoktası (UtilityNode) soyut sınıfları türetilmiştir. Ayrıca ă̆ modelinde bulunmayan teknik altyapı düğüm noktası taşıyıcılarını temsil etmek için TeknikAltyapıDüğ̈̈mNoktaTaşıyıcı (UtilityNodeContainer) sınıfı ile profildeki tüm sınıflara ait öznitelikleri içeren soyut TeknikAltyapıĂ̆Elemanı (UtilityNetworkElement) sınıfı eklenmiştir. Bu öznitelikler, tesisin durumu, zamansal özellikleri, zemine göre düşey konumu gibi özellikleri içerir. Birden fazla teknik altyapı ağında mevcut olabilen (ortak) tesisler, bu soyut sınıfların genişletilmesiyle oluşturulan sınıflarla temsil edilmektedir. Bu ortak tesisler; (1) düğüm noktaları olan Donatı (Appurtenance), (2) düğüm noktası taşıyıcıları olan Kabin (Cabinet), Direk (Pole), Kule (Tower) ve Menhol (Manhole) ile (3) teknik altyapı hat dizileri olan Kanal (Duct), Kablo (Cable) ve Boru (Pipe) sınıflarında temsil edilmektedir (Şekil 1b). 


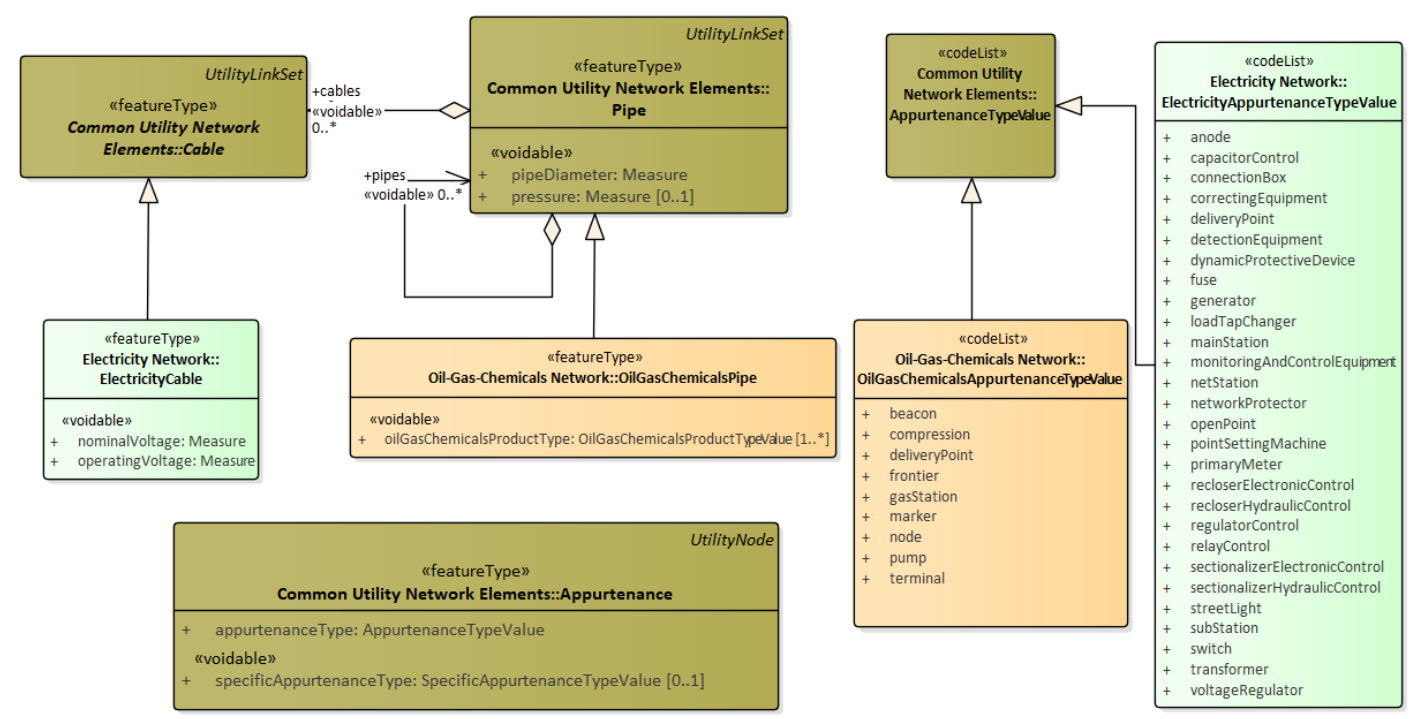

Şekil 2: INSPIRE elektrik ve petrol, gaz, kimyasal ağlar uygulama şemalarının türetilmesi

Ortak altyapı ağları uygulama şemasında yer alan Kablo ve Boru sınıfları; (1) elektrik, (2) petrol, kimyasal ve doğal gaz, (3) su, (4) kanalizasyon, (5) termal ve (6) elektronik haberleşme türündeki ağlar için genişletilmiş ve her bir ağ için ayrı uygulama

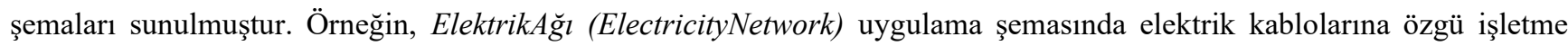
gerilimi ile nominal gerilim özellikleri, kablo sınıfından türetilen ElektrikKablo (ElectricityCable) sınıfı ile temsil edilmektedir (Şekil 2). Benzer şekilde, PetrolGazKimyasalAğBorusu (OilGasChemicalsPipe), ortak altyapı elemanı olan Boru sınıfından türetilmiştir. Ağlarda nokta özelliği gösteren tesisler, hem ortak altyapı ağları uygulama şemasında hem de sektörel şemalarda Donatı (Appurtenance) sınıfında yer almaktadır. Donatı sınıfı, donatı tipini ifade eden özniteliklere sahiptir; bu özniteliklerin değerleri her şema için geliştirilen değer listelerinden (örneğin, ElectricityAppurtenanceTypeValue) derlenir.

INSPIRE-UN modeli, teknik altyapı tesislerini 2 boyutlu modellemektedir. Yükseklik, derinlik bilgisi modelde yer almamaktadır. INSPIRE-UN spesifikasyonu veriyi mümkün olduğunca kapsamlı ve yüksek çözünürlükte (detay düzeyinde) tutmayı amaçlamış, ama gerektiğinde (ulusal ve Avrupa düzeylerindeki veri paylaşımı) detay düzeyinin azaltılmasına ve geometrinin basitleştirilmesine olanak tanımıştır (INSPIRE, 2013, s. 56).

\subsubsection{INSPIRE-UN Modelinin UygulamalarI}

Kablo ve Boru Hatları Bilgi Modeli (Informatiemodel Kabels en Leidingen, IMKL): Hollanda'da Kablo ve Boru Hatları Bilgi Merkezi (Kabels en Leidingen Informatie Centrum, KLIC), altyapı inşaatları sırasında meydana gelebilecek hasarların engellenmesi için kuruluşlar arasında çevrim içi veri değişimini sağlamayı amaçlayan ulusal düzeyde faaliyet gösteren bir merkezdir ${ }^{1}$. Çevrim içi KLIC portalı veri değişiminin vektörel formatta ve standart bir şemaya uygun biçimde gerçekleştirilmesini sağlayarak veri değişim sürecini iyileştirmek için Hollanda ulusal haritacılık ve kadastro kurumu olan Kadaster tarafından geliştirilmiş ve kullanıma sunulmuştur. Bir bölgede kazı yapmayı planlayan kişilerin bu merkeze başvurmaları ve planlanan çalışma bölgesinde faaliyet gösteren teknik altyapı kuruluşlarının konumsal verilerini merkez aracılığıyla paylaşmaları zorunlu tutulmuştur. Veri paylaşımında IMKL (Informatiemodel Kabels en Leidingen) uygulama şeması kullanılmaktadır. IMKL, ulusal coğrafi veri standartları kurumu olan Geonovum tarafindan ulusal mevzuat

\footnotetext{
${ }^{1}$ https://www.kadaster.nl/zakelijk/registraties/landelijke-voorzieningen/klic
} 
hükümlerine uygun biçimde INSPIRE-UN veri teması temel alınarak geliştirilmiştir (van den Brink, Janssen, \& Quak, 2017). Teknik altyapı kuruluşları tarafından IMKL şemasına uygun olarak üretilen GML formatındaki veriler, KLIC-viewer yazılımı aracılığıyla görüntülenebilmektedir².

IMKL modeli, (1) planlanan inşaat çalışmasında alınması gereken güvenlik önlemleri, taraflara ilişkin veriler, çalışma bölgesinin sınırları, planlanan kazı tarihi ve süresi gibi inşaat sürecine ilişkin veriler, (2) INSPIRE-UN modeli tarafindan sunulan teknik altyapı tesislerine ait 2 boyutlu coğrafi veriler ve öznitelik verileri ve (3) INSPIRE-UN modelinde kapsam dışı tutulan teknik altyapı tesislerine ait derinlik verisi ve özellikleri ile 3 boyutlu temsile yönelik tanımlamalar içermektedir. Model 3 boyutlu temsil için harici belgelerin eklenmesine de olanak vermektedir (Geonovum, 2015). Ribberink (2017), IMKL modeline ait bazı sınıfları kullanarak bir veri tabanı oluşturmuş, verilerin web sunucusu üzerinden paylaşımına olanak veren bir uygulama aracılığıyla; (1) kavşak inşaatı, (2) müşteri bağlantılarının kurulması ve (3) arıza ve onarım süreçlerinde inşaatçılar ile teknik altyapı kuruluşları arasındaki veri değişimi için IMKL modelinin kullanılabileceğini göstermiştir.

Star-DT: Fransa'da teknik altyapı çalışmaları sırasında insanların ve çevrenin korunması ile teknik altyapı hizmetlerinin kesintisiz sağlanması, teknik altyapı çalışmalarında koordinasyonunun sağlanması için Ulusal Coğrafi Bilgi Konseyi (Conseil National de l'Informatıon Geographique-CNIG) tarafından Star-DT adı verilen bir coğrafi veri modeli geliştirilmiş̧tir. Bu model, INSPIRE-UN modeli ile Hollanda tarafindan kullanılan IMKL modeli temel alınarak Fransa'daki uygulama gereksinimleri doğrultusunda, ölçme yöntemi, derinlik bilgileri, konum doğruluğu, proje yönetimi, kazı güvenliği tedbirleri gibi bilgileri temsil edecek biçimde geliştirilmiştir ${ }^{3}$.

Türkiye Ulusal Coğrafi Bilgi Sistemi (TUCBS) Altyapı Ağları Veri Teması: Türkiye'de ulusal coğrafi bilgi altyapısı kurulmasına yönelik çalışmalar, 1 sayılı Cumhurbaşkanlığı Kararnamesi gereği Çevre ve Şehircilik Bakanlığı Coğrafi Bilgi Sistemleri Genel Müdürlüğü (CBSGM) tarafından yürütülmektedir. Türkiye Ulusal Coğrafi Bilgi Sistemi Altyapısının Kurulumu (TUCBS) Projesi, ülkemizde INSPIRE Direktifine uygun coğrafi bilgi sistemi altyapısı kurulmasını, kamu kuruluşlarının sorumlu oldukları verilerin paylaşımına yönelik standartlar belirlemeyi amaçlamaktadır. Proje kapsamında 32 veri teması belirlenmiş; teknik altyapı ağları dahil olmak üzere 20 temaya ait coğrafi veri şeması üretilmiştir. Teknik altyapı tesislerine yönelik uygulama şemaları, (1) ortak ağ elemanları, (2) elektrik ağları, (3) petrol/gaz/kimyasal ağları, (4) atık su ağları, (5) su ağları, (6) elektronik haberleşme ağları, (7) termal ağlar olmak üzere yedi uygulama şemasını içermektedir ${ }^{4}$.

Uygulama şemaları, INSPIRE uygulama şemaları ve teknik altyapı kuruluşları temsilcilerinin görüşleri temel alınarak geliştirilmiştir. Şemalar, teknik altyapı tesislerinin fiziksel ve konumsal özellikleri, verilerin konumsal doğruluğu gibi öğeleri içermekte, ayrıca kartografik gösterimlerine yönelik kurallar sunmaktadır. Uygulama şemalarının; altyapı kaynaklarının planlanması, su kaynaklarının yönetimi, arazi kullanımı, kıyı alanlarının yönetimi, tehlikeli atıkların yönetimi, ulusal çevre eylem planlarının hazırlanmasında kullanımı öngörülmüştür (CBSGM, 2020).

\subsection{CityGML Teknik Altyapı Ağları Uygulama Uzantısı}

CityGML, 3 boyutlu kent modeli verilerinin saklanması ve değişimi/transferi için XML tabanlı bir format sağlayan açık bir veri modelidir. 2012 yılında bir OGC standardı olarak yayımlanan 2.0 versiyonu, GML3 (GML 3.1.1) için bir uygulama şeması sunmaktadır. 3 boyutlu kent nesnelerine ait semantik ve konumsal bilgilerin çeşitli detay düzeylerinde temsilini, ayrıca farklı uygulamalar arasında paylaşımını destekler. Model; bina, köprü, kent mobilyası, arazi kullanımı, su kütleleri, tüneller gibi 13 kent nesnesi temasına ait sınıflar içermektedir. Teknik altyapı tesisleri, standardın mevcut versiyonunda veya

\footnotetext{
${ }^{2}$ https://www.klicviewer.nl/klic-viewer/

${ }^{3}$ http://cnig.gouv.fr/wp-content/uploads/2019/11/CNIG_STAR-DT_v1.0.pdf

${ }^{4}$ https://cbs.csb.gov.tr/cografi-veri-temalari-uygulama-semalari-i-86098
} 
geliştirilmekte olan 3.0 versiyonunda yer almamaktadır (Kutzner, Chaturvedi, \& Kolbe, 2020). Ancak, CityGML'de kapsam dışı tutulan farklı alanlara özgü bilgiler, tanımlanmış sınıfların genişletilmesiyle veya CityGML şema tanımlamalarını temel alan yeni formel XML şemaların geliştirilmesiyle oluşturulan uygulama uzantılarıyla (Application Domain Extension - ADE) modellenebilmektedir (Kolbe, 2009; van den Brink, Stoter, \& Zlatanova, 2013). Biljecki, Kumar ve Nagel (2018), yayımlanmış 44 farklı uygulama uzantısı bulunduğunu belirlemiştir.

Teknik Altyapı Ağları Uygulama Uzantısı (Utility Network ADE, UNADE), teknik altyapı tesislerine ait bilgilerin CityGML formatındaki kent nesneleriyle entegre bir biçimde temsil edilmesini sağlayan bir uygulama şemasıdır. Başlangıçta afet durumlarında teknik altyapı tesislerinin birbirlerine ve diğer kent nesnelerine etkilerinin simüle edilmesi hedeflenmiş, bu doğrultuda teknik altyapı tesislerinin karşılıklı bağımlılıklarını temsil eden 3 boyutlu bir ağ yapısı önerilmiştir (Becker, Nagel, \& Kolbe, 2011). Ardından uygulama uzantısı teknik altyapı nesne ile ağlarının fiziksel (Becker, Nagel, \& Kolbe, 2013) ve işlevsel özelliklerinin temsil edilmesine olanak verecek biçimde güncellenmiştir (Kutzner \& Kolbe, 2016). Halen geliştirilmekte olan modele GitHub deposundan erişilebilmektedir ${ }^{5}$.

UNADE'nin özünü oluşturan ağ yapısı, teknik altyapı tesislerinin hem detaylı 3 boyutlu geometrileriyle topografik hem de 2 boyutlu (GM_Point ve GM_Curve temel tipleriyle) topolojik yapıda temsilini sağlamaktadır (Şekil 3). A $\breve{g}$ (Network) sınıfı topografik, A $\breve{g} G r a f i$ (NetworkGraph) sınıfı ise topolojik biçimde temsil edilen ağları ifade eder. SoyutAğDetayı

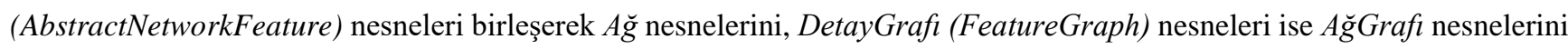
oluşturur.

A $\breve{g} G r a f ı$, Düğ̈̈mNoktası (Node) ve Bağlantı (AbstractLink) nesnelerinden oluşur. Burada bağlantılar; (1) farklı türdeki veya hiyerarşideki ağlar (örneğin, iletim hattı ve dağıtım hattı) arasında, (2) aynı tür ağda farklı nesneler (ör., boru-vana-boru) arasında ya da (3) bir nesnenin başlangıç ve sonu arasında yer alabilir. Bu bağlantılar sırasıyla Ă̆Bağlantısı (NetworkLink), DetaylarArasıBağlantı (InterFeatureLink) ve DetayÍçBağlantısı (InteriorFeatureLink) sınıflarıyla temsil edilir (Şekil 3).

\footnotetext{
${ }^{5}$ https://github.com/TatjanaKutzner/CityGML-UtilityNetwork-ADE/
} 


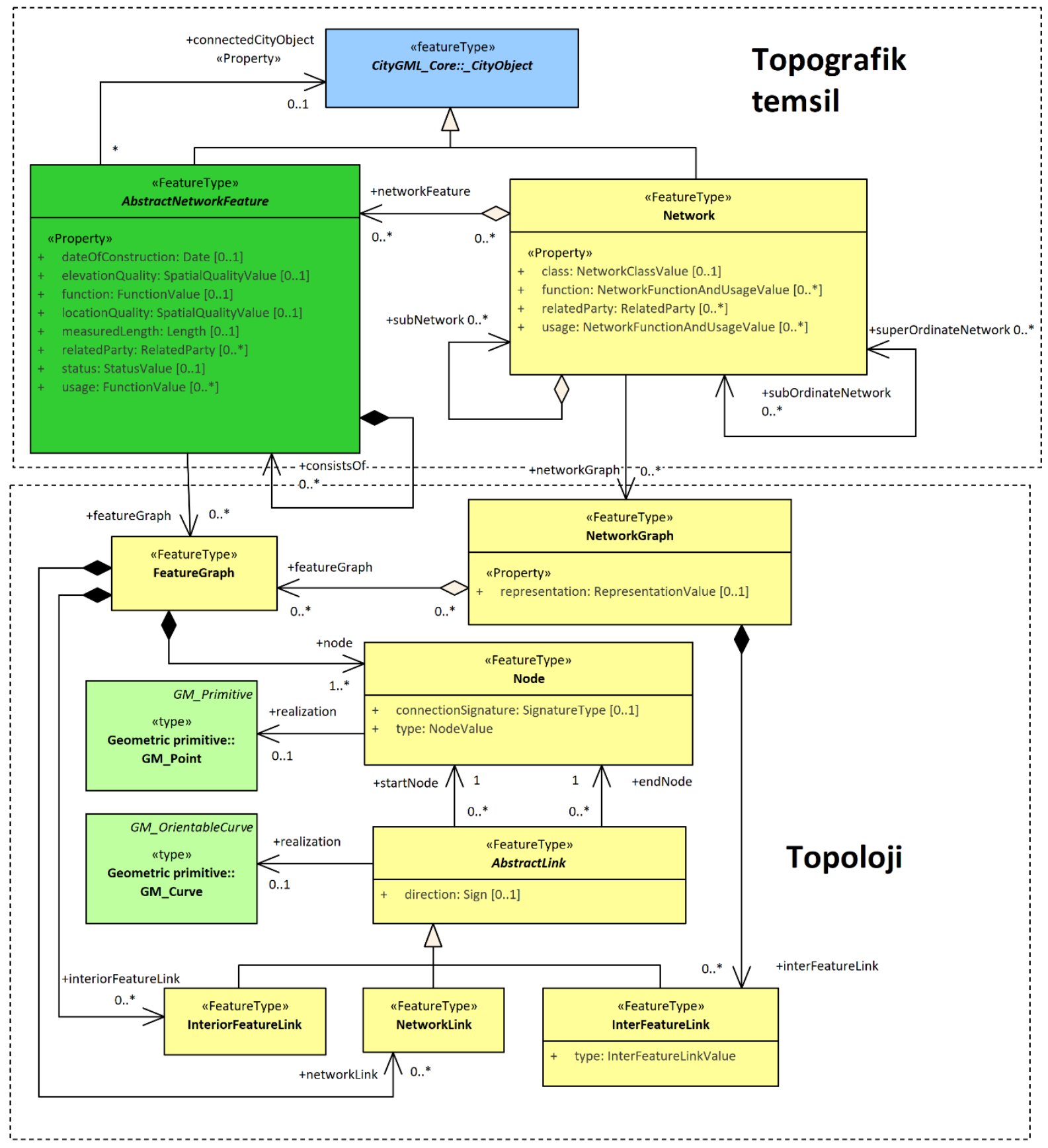

Şekil 3: UNADE ağ modeli ve topoloji temsili

UNADE, ağ modeliyle ilişkili dört farklı modül içermektedir. Bunlar; (1) ağ bileşenleri, (2) ağ özellikleri, (3) malzeme özellikleri ve (4) işlevsel özelliklerdir. Şekil 4'te bu modüllere ait sınıflar sırasıyla mavi, turuncu, sarı ve pembe renkler ile gösterilmektedir.

A ̆̆ bileşenleri modülünde altyapı ağlarını oluşturan elemanların/tesislerin ölçü, eğim, şekil özellikleri, konumu, konum doğruluğu, ilgili kurum, kullanım durumu gibi genel topografik ve işlevsel özellikleri tanımlanır. Ağ bileşenleri; (1) boru, kanal kablo gibi dağıtım tesisleri; (2) depolama, ölçme, izleme, kontrol gibi görevleri bulunan, menhol, vana, transformatör gibi işlevsel elemanları ile (3) tesisleri çevreleyen ve koruyan yapıları içerir. Teknik altyapı tesisleri ve bileşenleri ayrı ayrı, bu soyut sınıflardan türetilen alt sınıflarla tanımlanır (Şekil 4). Bu sınıfların tamamı, SoyutAğDetayı (AbstractNetworkFeature) sınıfının alt sınıflarıdır. A $\breve{g}$ bileşenleri böylelikle farklı geometri özellikleriyle temsil edilebilir (Şekil 5), birleşerek bir teknik altyapı ağını oluşturabilir, aynı zamanda topolojik bir yapıda tanımlanabilir (Şekil 3). 
Altyapı ağlarının uç noktaları olan aydınlatma direği, yangın musluğu vb. gibi nesneler UNADE modelinde yer almamaktadır. Bu nesneler, CityGML'de kent mobilyaları ile temsil edilir. Teknik altyapı tesislerinin kent nesneleriyle ilişkileri, SoyutAğDetayı sınıfı ile CityGML modelinde herhangi bir kent nesnesinin tanımlandığı KentNesnesi (_CityObject) sınıfı arasındaki ilişkiyle sağlanmaktadır.

A ̆̆ özellikleri modülü, teknik altyapı tesisleri tarafından taşınan maddeler ile maddelerin sıcaklık, yoğunluk, basınç, iletkenlik, yanıcılık gibi özelliklerini ifade etmektedir. Bu nesneler, $A \breve{g}$ (Network) sınıfı ile ilişkilendirilmiştir.

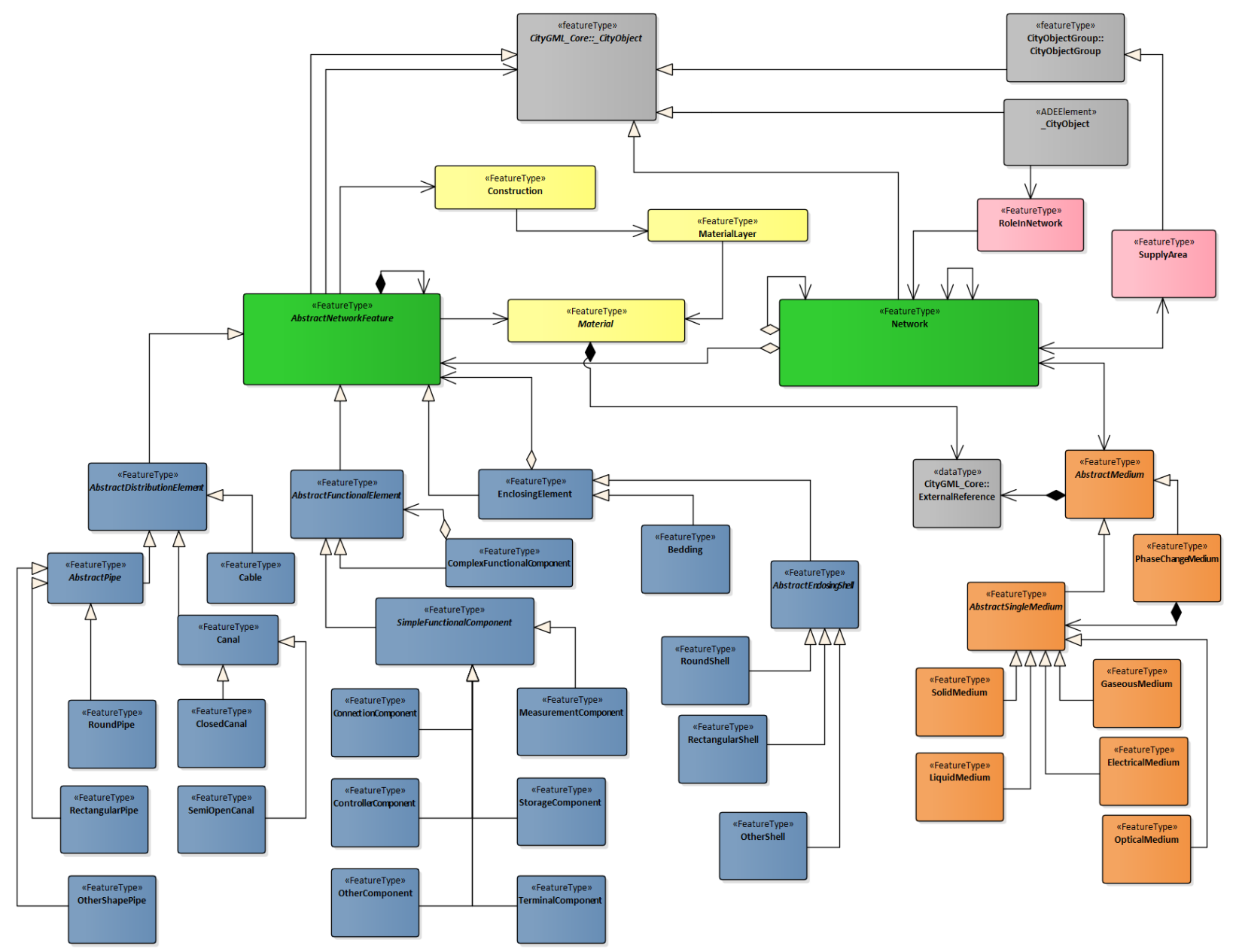

Şekil 4: UNADE modülleri. Mavi renk ağ bileşenlerine, turuncu renk ağ özelliklerine, sarı renk malzeme özelliklerine, pembe renk işlevsel özelliklere ait sınıfları göstermektedir

A $\breve{~ b i l e s ̧ e n l e r i n i n ~ i c ̧ ~ v e ~ d ı s ̧ ~ k a t m a n l a r ı n ı n ~ y a p ı m ~ v e ~ m a l z e m e ~ o ̈ z e l l i k l e r i, ~ m a l z e m e ~ m o d u ̈ l u ̈ n d e ~ Y a p ı ~(C o n s t r u c t i o n), ~}$ MalzemeKatmanı (MaterialLayer) ve Malzeme (Material) sinıflarıla temsil edilir. 


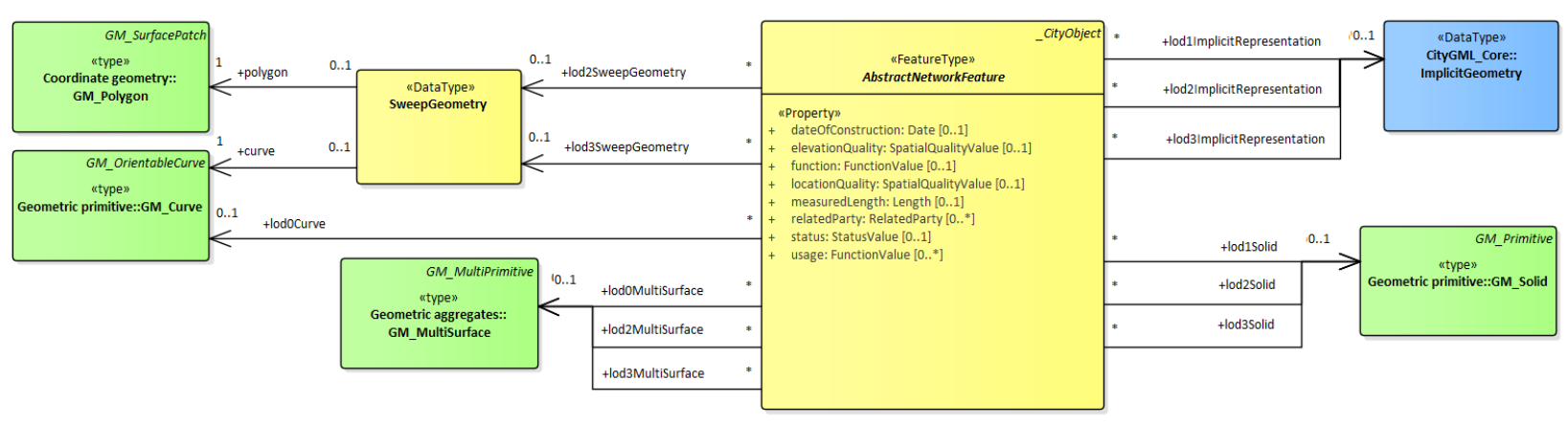

Şekil 5: UNADE modelinde ağ bileşen geometrileri

İşlevsel özellikler modülü, altyapı tesislerinin ve ağlarının işlevleri ile hizmet sundukları bölgeleri tanımlamak için kullanılmaktadır. Bir teknik altyapı ağının beslediği alan, BeslemeAlanı (SupplyArea) sınıfı ile temsil edilebilir. Bu sınıf, CityGML modelinde yer alan KentNesneGrubu (CityObjectGroup) sınıfının alt sınıfıdır. Böylelikle, bir ağın beslediği bölge kent ile ilişkilendirilebilmektedir. Bu ilişki, işletme sürecindeki olası hizmet kesintilerinden etkilenecek nüfus, yapı ve bölgelerin belirlenmesini sağlar (Kutzner \& Kolbe, 2016).

Altyapı tesisleri ile kent nesnelerini ve bunların arasındaki ilişkileri temsil etmek, farklı kullanım durumlarının gerektirdiği coğrafi analizleri yapabilmek için coğrafi veri yönetim sistemlerine gereksinim duyulur. CityGML formatındaki verilerin yönetimi için geliştirilmiş bir veri tabanı şeması sunan 3DCityDB (Yao vd., 2018), UNADE için de kullanılabilir (Boates, Agugiaro, \& Nichersu, 2018). Örneğin, den Duijn, Agugiaro, ve Zlatanova (2018); teknik altyapı tesisleri ile kent nesneleri arasındaki ilişkileri temsil etmek üzere Rotterdam şehrindeki alçak gerilimli elektrik hatları ile su şebekesine ait yer altındaki kablo ve borular için ADE sınıflarını, yer üstündeki direkler ve menholler için ise CityGML sınıflarını kullanarak bir veri tabanı oluşturmuş, böyle bir yaklaşımla 3 boyutlu altyapı ağ analizlerinin 3 boyutlu kent modelleri kapsamında gerçekleştirilebileceğini göstermiş̧tir. Benzer biçimde, Boates vd. (2018) su dağıtım şebekesine ait coğrafi verileri CityGML verileriyle entegre ederek, toplam şebeke hacminin hesaplanmasını ve depolar ile binalar arasında güzergah analizlerini gerçekleştirmiş; Vishnu ve Saran (2018), su dağıtım şebekesi elemanlarının devre dışı kalması halinde etkilenen bölgeleri ve teknik altyapı tesislerinin bulundukları yol alanlarını sorgulayarak belirlemiştir.

Ayrıca, modelin işlevselliğini artırmak amacıyla genişletilmesini öneren kimi çalışmalar bulunmaktadır. Fossatti, Agugiaro, olde Scholtenhuis ve Dorée (2020), farklı sektörlere ait tesislerin bakım ve onarım faaliyetlerinde bu modelin genişletilerek kullanılabileceğini ortaya koymuştur. olde Scholtenhuis, den Duijn, ve Zlatanova (2018), kablo ve boru gibi dağıtım tesislerine ait coğrafi veri kalitesinin (konum doğruluklarının) modele dahil edilmesi için bir eklenti önermiş, böylelikle tesislerin konum belirsizlikleriyle beraber görselleştirilebilmesini sağlamıştır.

\subsection{Endüstri Temel Sınıfları}

Endüstri Temel Sınıfları (Industry Foundation Classes, IFC); tasarım, inşaat, tedarik ve bakım işlemleri gibi süreçlerde kullanılan Yapı Bilgi Modelleme (Building Information Modeling, BIM) sistemlerine ait verilerin farklı kullanıc1 ve yazılımlar arasında paylaşımı için buildingSmart tarafından geliştirilmiş bir standarttır. IFC, ayrıca bir ISO (16738:2018) standardıdır. Çoğunlukla mimarlık, mühendislik ve inşaat sektörlerinde veri değişimi için kullanılmaktadır. IFC, ISO:1030311 standardında tanımlanan EXPRESS modelleme dilinde ve XML şema tanımlama dilinde sunulmakta, birçok yazılım tarafından desteklenmektedir. Veri değişiminde genellikle model görünüm tanımlamaları (Model View Definition, MVD) kullanılır. Bunlar, çok kapsamlı ve karmaşık bir yapıya sahip olan IFC modelinin, yalnızca gereksinim duyulan verilerin değişimi için oluşturulmuş alt kümeleridir. 
IFC'de yapıların kendilerini meydana getiren elemanları ile bu elemanların boyut, malzeme, fiyat gibi özellikleri kaydedilir. Yapıların içindeki ve bulundukları arazideki teknik altyapı tesislerinin iki ve üç boyutlu temsilini destekler.

IFC modeli, bir dizi (alt) şemadan oluşur ve her şema kavramsal bir katmana aittir (Şekil 6). Bu katmanlar; (1) kaynak tanımlama katmanı (resource layer), (2) öz katman (core layer), (3) birlikte çalışabilirlik katmanı (interoperability layer) ve (4) alan katmanıdır (domain layer).

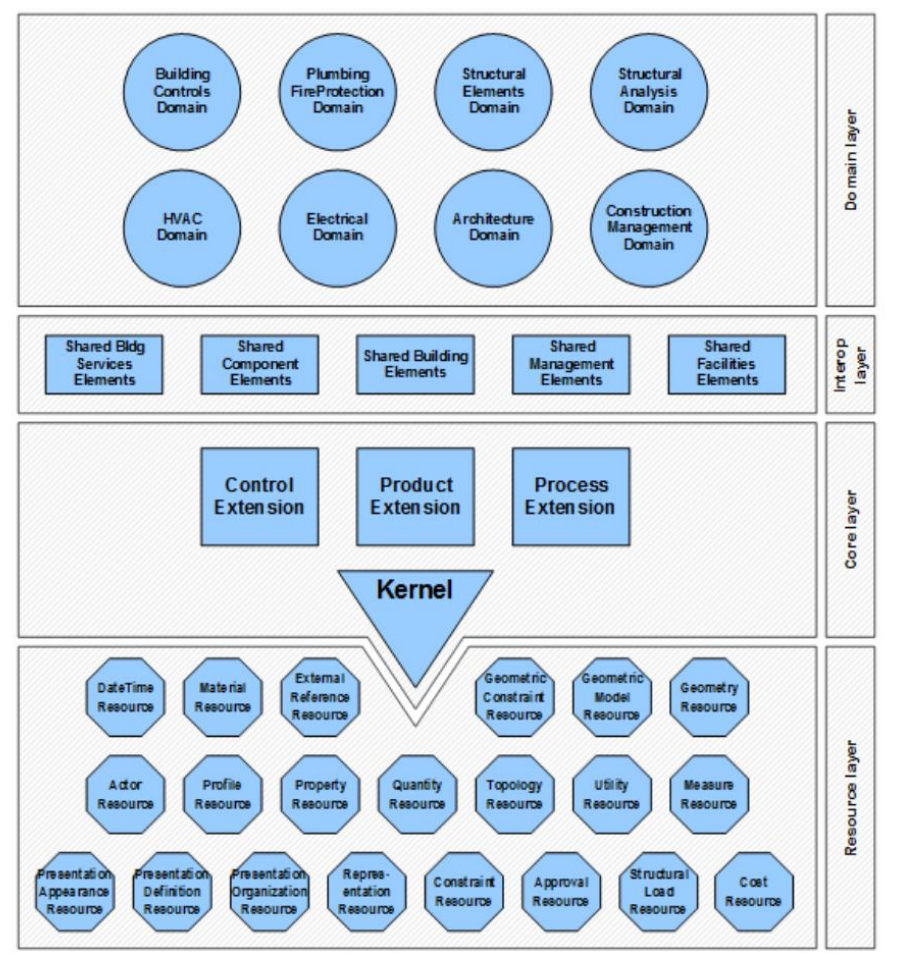

Şekil 6: IFC'de tanımlanan kavramsal katmanlar ile şemalar (buildingSMART, 2018a)

1) Kaynak tanımlama katmanı, tüm şemalarda kullanılabilecek temel kavramları ve genel (jenerik) öğeleri içerir (buildingSMART, 2018b). Bu katmandaki öğeler tek başlarına kullanılamaz ve genellikle diğer katmanlardaki nesnelerin değer tipleri olarak tanımlanır. Burada, kaynak olarak tanımlı tiplerin bazıları; geometri (geometry resource, geometric model resource) ve topoloji (topology resource) ile ölçü birimleri (measure resource) türleridir.

IFC şemasındaki geometri tipleri ISO 10303-42 standardında tanımlanmıştır. Bu tipler, nesnelerin 2 (ĕgri: IfcCurve, yüzey: IfcSurface vb.) ve 3 boyutlu (katı cisim modeli: IfcSolidModel) biçimde tanımlanmasına olanak verir. Şekil 7'de mavi, pembe, yeşil ve gri renkler sırasıyla, kaynak tanımlama katmanında yer alan TemsilKaynağı (IfcRepresentationResource), GeometrikSınırlamaKaynăğ (IfcGeometricConstraintResource), GeometriKaynăgl (IfcGeometryResource), GeometrikModelKaynă̆ (IfcGeometricModelResource) şemalarına ait sınıfları göstermektedir. TemsilKaynă̆l, nesnelerin şekilsel ve topolojik özelliklerini tanımlar. GeometrikSınırlamaKaynă̆g, temsil edilen nesnelerin konumlandırılması için gereken kaynakları belirtir. GeometriKaynă̆g, nesne geometrilerinin temsili için kullanılan kaynakları tanımlar. Bu kaynak kullanılarak nesneler şekilleri veya geometrileriyle temsil edilir. GeometrikModelKaynă̆ı katı cisim veya yüzey modelleri gibi geometrik modelleri tanımlar. 


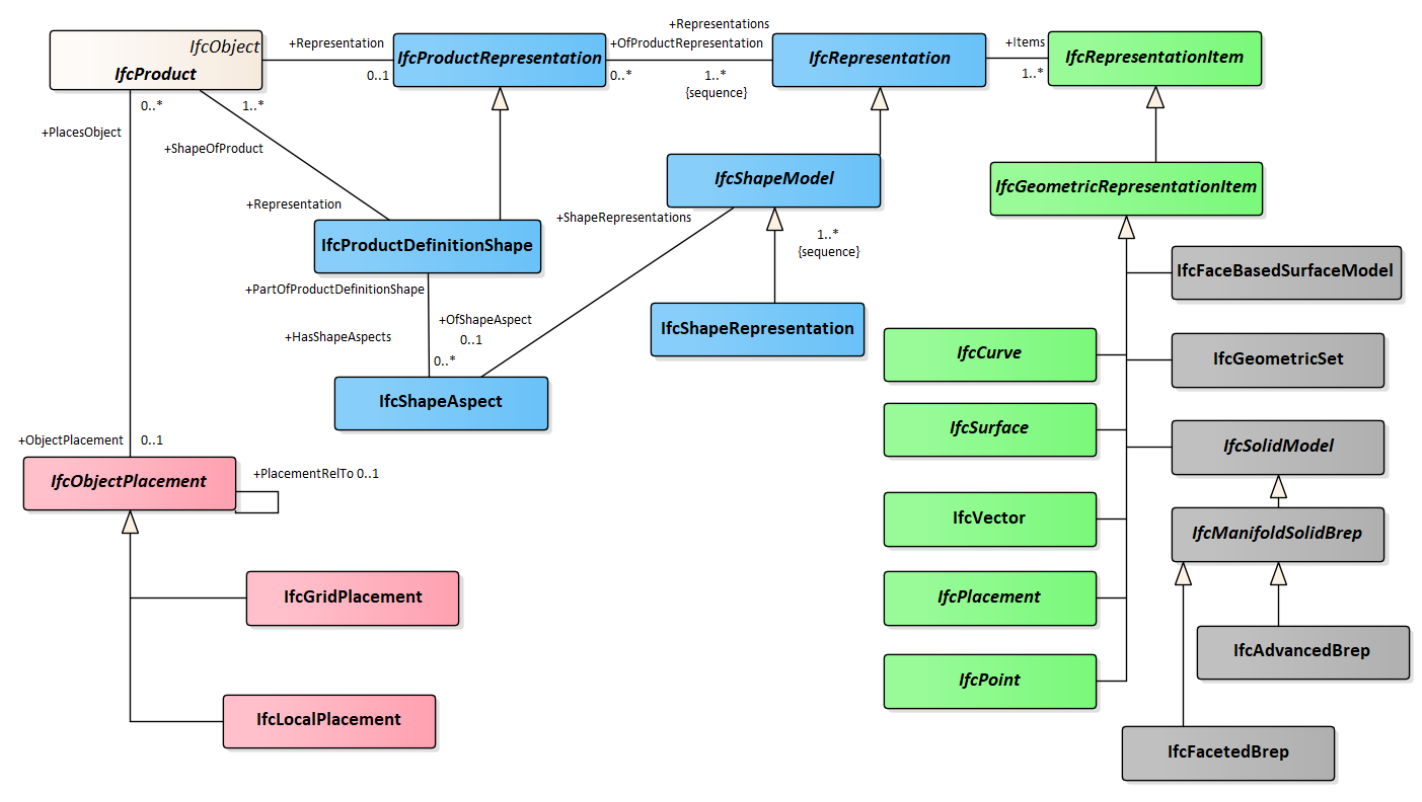

Şekil 7: IFC'de ürünlerin konumsal ve geometrik temsili

2) Öz katman, çekirdek (kernel) şema ile bunlardan türetilen; ürünlere, süreç yönetimine ve kontrole yönelik tanımlamaların temelini oluşturan, sırasıyla IfcProductExtension, IfcProcessExtension ve IfcControlExtension isimli şemaları kapsamaktadır (buildingSMART, 2018c).

Çekirdek şema, bütün öğeler için üst sınıf olan IfcRoot sınıfını içerir. IfcRoot, ürün ve süreç yönetimi gibi farklı alanlara ait nesnelerin genel tanımlarını içeren NesneTanımlama (IfcObjectDefinition) şeması ile genişletilmiştir. Bu şema ürün ve süreç yönetimi gibi farklı alanlara ait nesnelerin genel tanımlarını içerir. IFC'de ürün terimi, geometrik olarak temsil edilen ya da belirli bir konumda bulunan nesneler için kullanılan genel bir kavramdır. Bu nesneler, çekirdek şemada Ürün (IfcProduct) sınıfı ile ifade edilmektedir. Ürünlerin konumları, yerel veya küresel koordinat sisteminde ya da başka bir nesneye göre bağıl olarak, NesneKonumlandırma (IfcObjectPlacement) ile ifade edilebilmektedir. Şekil 7'de ürünlerin konumsal ve geometrik temsili için kullanılan sınıf ile ilişkiler gösterilmektedir. Geometrik olarak, temsil (representation) özelliği (özniteliği) ile ÜrünŞekilTanımı (IfcProductDefinitionShape) tipinde tanımlanarak, aynı anda birden fazla şekilde temsil edilebilir.

Öz katmanda yer alan şemalardan biri olan ÜrünEklentisi (IfcProductExtension) çekirdek şemayı fiziksel nesnelere ilişkin sınıflarla genişletir. Yapılardaki fiziksel elemanlar bu şemada Ürün (IfcProduct) sınıfindan türetilen Eleman (IfcElement) nesneleriyle ifade edilmektedir.

ÜrünEklentisi şeması teknik altyapı tesisleri için kullanılan DağgttmElemanı (IfcDistributionElement), BağlantıNoktası (IfcPort) ve Sistem (IfcSystem) temel sınıflarını içermektedir. Bu sınıflar, bir alt katman olan birlikte çalışabilirlik katmanında detaylandırılmaktadır. DağıtımElemanı, ısıtma, havalandırma, iklimlendirme, shhhi tesisat ve yangından korunma, elektrik, elektronik haberleşme alanlarındaki fiziksel teknik altyapı tesisleri için tanımlanmış soyut bir sınıftır. BağlantıNoktası, nesneler arasındaki bağlantıları ifade eder. Elemanlar ve bağlantı noktaları arasındaki bağlılık, BağlantıNoktasıElemanIllişkisi (IfcRelConnectsPortToElement) ve Bă̆lantıNoktaillişkisi (IfcRelConnectsPorts) ilişki sınıfları ile temsil edilir (Şekil 8). 


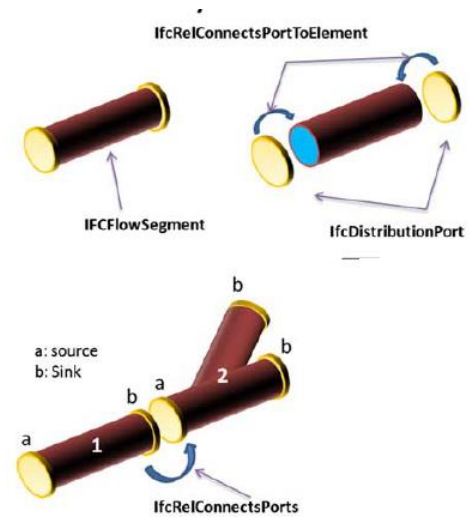

Şekil 8: IFC'de teknik altyapı tesis bağlantılarının gösterimi (Hijazi, Ehlers, \& Zlatanova, 2012, s. 32)

3) Birlikte çalışabilirlik katmanı, birden fazla disiplin tarafından kullanılan ve paylaşılan nesneleri içeren alt şemaları belirtir (buildingSMART, 2018d). Bu şemalarından biri olan, teknik altyapı tesislerinin temsil edildiği PaylaşılanBinaHizmetElemanları (IfcSharedBldgServiceElements), bina hizmetlerine yönelik disiplinler arasında birlikte çalışabilirliğin sağlanması için gereken temel tanımlamaları içermektedir. Burada bir üst katmanda yer alan (i) DağıtımElemanı, (ii) BağlantıNoktası ve (iii) Sistem sınıfları genişletilmektedir (Şekil 9):

i) Yapı içindeki teknik altyapı dağı̆ımına yarayan tesisler, DağıtımElemanı sınıfından türetilen DağgtımAkışElemanı (IfcDistributionFlowElement) sınıfı ve alt tipleri ile özelleştirilir (Şekil 9). Örneğin, AkışDenetçisi (IfcFlowController) ile vana veya anahtar gibi, madde ya da enerji akışını kontrol eden ve düzenleyen nesneler ifade edilir. AkışB̈̈lümü (IfcFlowSegment), bir dağıtım sistemindeki boru veya kanal gibi elemanların genellikle düz ve iki ucu bulunan bir bölümünü ifade eder (Şekil 8). Ayrıca, kompresör, pompa gibi nesnelerin akışını sağlayan tesisler (IfcFlowMovingDevice); tank gibi geçici depolama için kullanılan tesisler (IfcFlowStorageDevice); dirsek, manşon gibi bağlantı parçaları (IfcFlowFitting) temsil edilir. Bina otomasyon kontrol sistemlerine ait nesneler DağıtımKontrolElemanı (IfcDistributionControlElement) ile tanımlanır.

ii) Teknik altyapı tesislerine özgü bağlantı noktaları, akış yönü ile birlikte DağıtımBağlantıNoktası (IfcDistributionPort) ile ifade edilir (Şekil 8).

iii) Ortak bir amacı yerine getiren ya da aynı tür bina hizmetinde kullanılan tesislerin oluşturduğu bir dağıtım sistemi DağıtımSistemi (IfcDistributionSystem) ile temsil edilir.

4) Alan katmanı, belirli disiplinlere özgü şemaları içermektedir. Bunlar; (1) 1sıtma, havalandırma, iklimlendirme (IfcHvacDomain), (2) sthhi tesisat ve yangindan korunma (IfcPlumbingFireProtectionDomain), (3) elektrik (IfcElectricalDomain) ve (4) bina kontrol ve otomasyon sistemleri (IfcBuildingControlsDomain) için tanımlanmış şemalardır. 


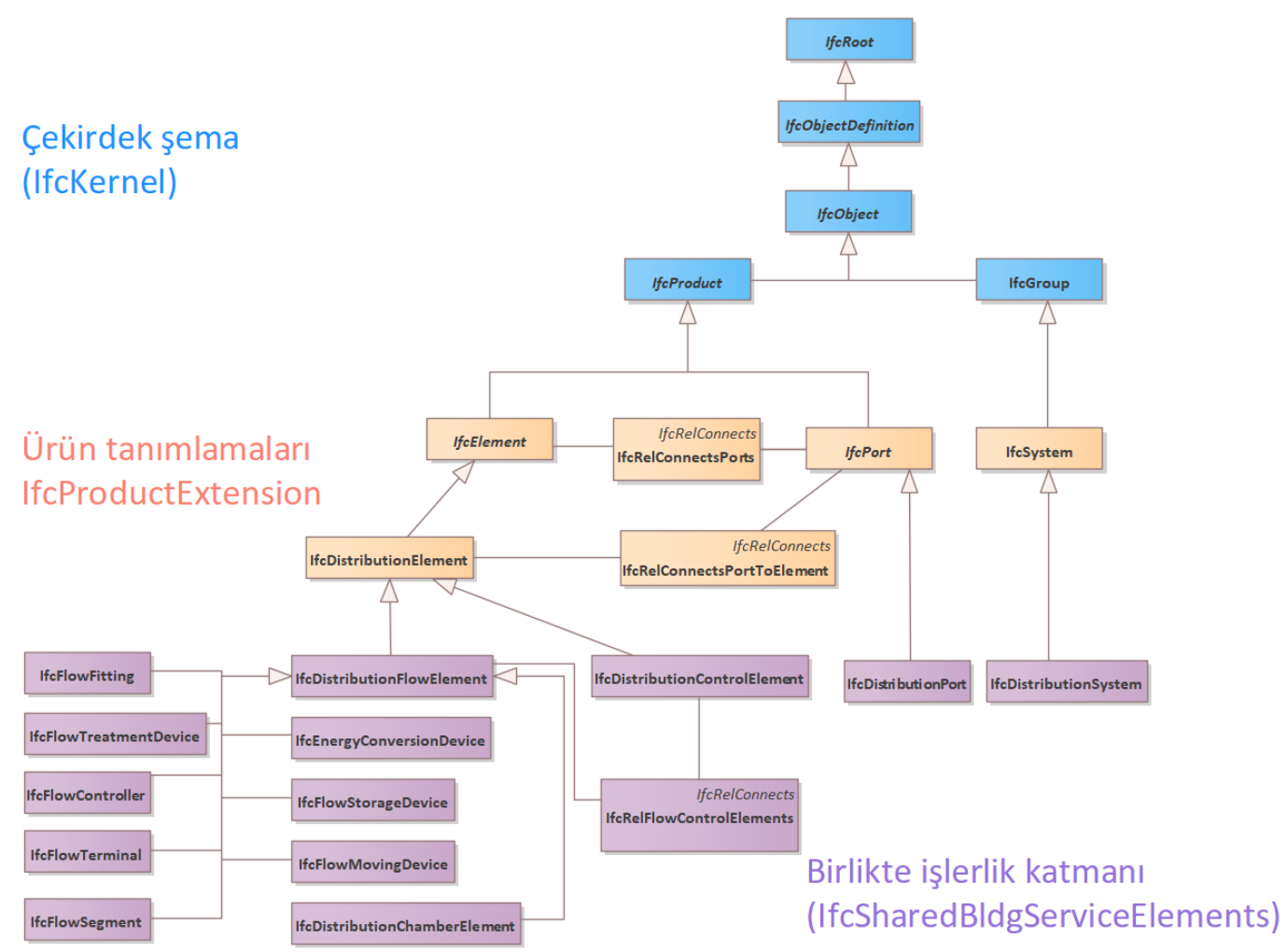

Şekil 9: IFC'de teknik altyapı tesislerine ilişkin sınıfların bir bölümünün UML gösterimi

IFC modeli, bina ve tesis yönetimine odaklanmakta, bu doğrultuda teknik altyapı tesislerinin kapsamı yapı içi ve bulundukları arazi ile sınırlı kalmaktadır. Dağııım ve iletim şebekelerine ait coğrafi verilerin yönetimi ve analizi için coğrafi bilgi sistemleri kullanılmaktadır. Yapı düzeyindeki teknik altyapı verilerinin coğrafi/kent bilgi sistemleriyle bütünleştirilerek coğrafi analizlerde kullanılmasını ve görselleştirilmesini sağlamak için BIM ve CBS modellerinin entegre edilmesi gerekmektedir (Cheng \& Deng, 2015). Bu amaçla genellikle IFC ve UNADE modelleri eşleştirilmekte ve tümleşik modeller ile entegre edilmektedir. Bu amaçla yapılan çalışmalar, IFC şemasındaki teknik altyapı tesislerine ilişkin birçok nesnenin UNADE modeliyle veri kaybı olmadan eşleştirilebildiğini göstermiştir (Hijazi, Ehlers, Zlatanova, \& Isikdag, 2009; Hijazi, Ehlers, Zlatanova, Becker, \& Berlo, 2011; Hijazi vd., 2012).

Wang, Deng, Won ve Cheng (2019), IFC ve UNADE modellerini teknik altyapı şebekelerinin projelendirme, işletme ve bakım süreçlerindeki veri gereksinimleri doğrultusunda genişletmiş ve tümleşik bir model tasarlamıştır. Benzer şekilde Zhao, Liu ve Mbachu (2019) su dağıtım şebekelerinin planlanmasında; Lee, Wang, Lo ve Long (2018) ise altyapı tünellerinin bakım süreçlerinin yönetiminde kullanılabileceğini göstermiş̧tir. Gilbert, Barr, James, Morley ve Ji (2018), dağıtım ağlarındaki elektrik arz ve taleplerini, IFC ve UNADE modellerinde temsil edilen ağlar ile dinamik kaynak akışlarını gösteren gerçek zamanlı sensör verilerini kullanan bir sistem aracılığıyla görselleştirmiştir.

\subsection{OGC LandInfra / InfraGML}

2016 yılında OGC standardı olarak yayımlanan Arazi ve Altyapı Kavramsal Modeli (Land and Infrastructure Conceptual Model, LandInfra), inşaat mühendisliği altyapı tesislerine ve araziye ilişkin kavramlar ve kavramlar arasındaki ilişkileri tanımlayan, uygulamadan bağımsız bir model sunmaktadır (OGC, 2016). Model, karayolu, demiryolu, köprü gibi altyapı tesislerine ait projelendirme ve ölçme süreçlerindeki coğrafi veri yönetimini desteklemektedir. LandInfra, teknik altyapı tesislerinden yalnızca ıslak altyapılar olarak tanımlanan drenaj, su dağııımı ve atık su altyapı tesislerini içermektedir; ancak mevcut versiyonda bu sınıflar detaylandırılmamıştır. Elektrik, telekomünikasyon, doğal gaz gibi teknik altyapı tesislerine ait 
projeler ile fiziksel bileşenler kapsam dışı tutulmuştur.

LandInfra' da birbirleriyle bağlantılı olan konular belirlenmiş ve kavramsal modelleri UML paketleri biçiminde sunulmuştur. Bunlar; Öz (Core), Tesis (Facility), Proje (Project), Gecki (Alignment), Karayolu (Road), Demiryolu (Railway), Ölçme (Survey), Arazi (LandFeautre), AraziBölümü (LandDivision), BinaBă̆ımsızBölüm (Condominium) paketleridir. 2017 yılında yayımlanan InfraGML standardı, LandInfra'da belirlenen sekiz temaya ait GML uygulama şemalarını (paketleri) tanımlamaktadır ${ }^{6}$. Modelin kapsadığı tesislere ait bileşenler Tesis paketinde; bunlara ait projelere ilişkin bilgiler Proje paketinde temsil edilmektedir. Ölçme paketi, ölçme cihazlarına, ham gözlemlere ve kestirimlere yönelik bilgilerin temsiline olanak verir. Fiziksel nesnelerin bir doğrusal referans sisteminde konumlandırılması için gereken tanımlamalar Gecki paketinde sunulmaktadır. AraziBölümü paketinde, idari ya da mülkiyet durumuna göre bölümlendirilmiş araziler temsil edilmektedir.

Her uygulama şemasının LandInfra (öz model) gereksinimlerini sağlaması gerekmektedir (OGC, 2017a). Şekil 10, bir LandInfra veri setinin (LandInfraDataset) tanımlayıcı bilgilerini, tüm paketlerde yer alan Detay (Feature) nesnelerini ve soyut verileri (AbstractData) tanımlayan öz paketi göstermektedir.

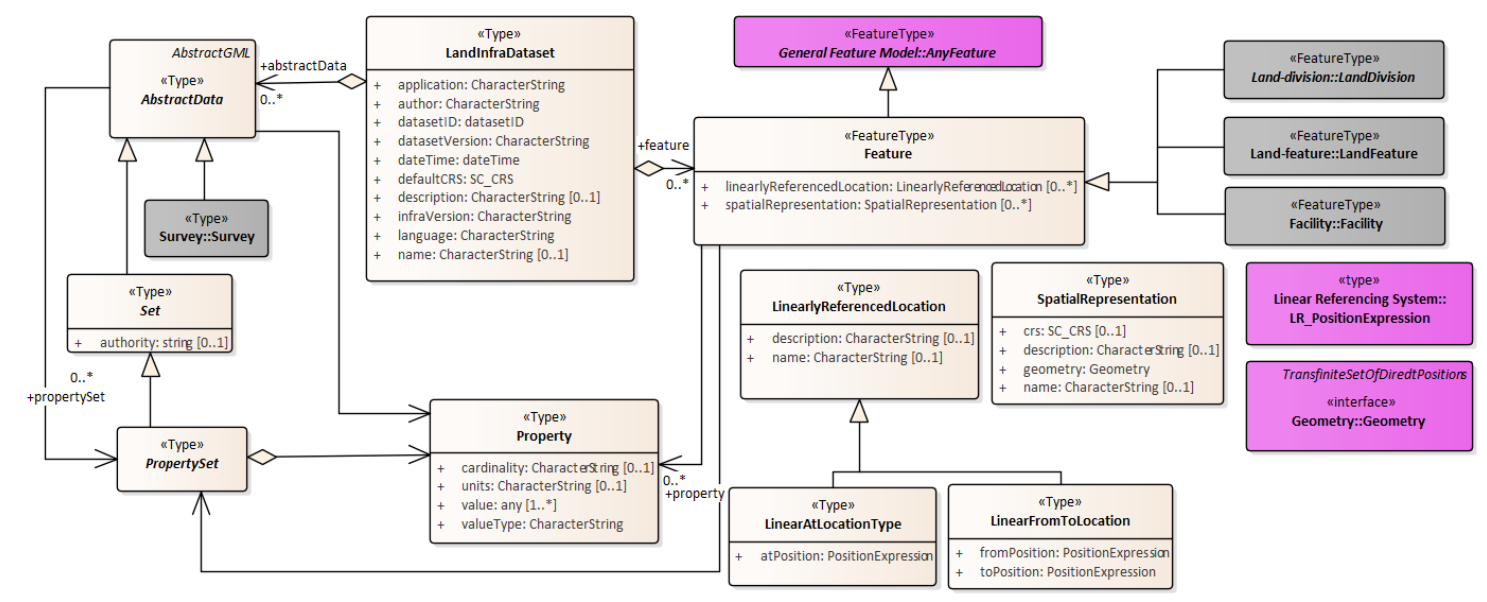

Şekil 10: LandInfra öz paketi

Detay sınıfı, gerçek dünya nesnelerini (feature) temsil eden detayları kapsar. ISO 19109:2015 standardında tanımlanan ve tüm detay nesneleri için ortak bir sınıf olan HerhangiBirDetay (AnyFeature) sınıfından türetilmiştir. Detaylar, doğrusal referanslandırma kullanılarak (linearlyReferencedLocation) ve/veya coğrafi olarak koordinat ve geometrileriyle (spatialRepresentation) temsil edilebilir. Doğrusal referanslandırma için ISO 19148:2012 standardında tanımlanan konum ifadesi (LR_PositionExpression) kullanılmaktadır. Coğrafi temsil için, LandInfra ve InfraGML’in yayımlandığı tarihlerde taslak halde bulunan ISO 19107:2019 standardında yer alan geometri temelleri (primitive) kullanılmıştır.

Bir veri seti (LandInfraDataSet, LandInfraVeriSeti), tanımlayıcısı, versiyonu, tarihi, dili, uygulaması gibi özellikleri ile tanımlanır ve Detay ile SoyutVeri sınıflarından türetilen detay ve tanımlamaları içerir. Bu sınıflar ve LandInfraVeriseti arasındaki toplama (aggregation) ilişkileri, farklı paketlere/temalara ait veri ve tanımlamaların aynı veri setinde yer almasına olanak verir.

\footnotetext{
${ }^{6}$ https://www.ogc.org/standards/infragml
} 


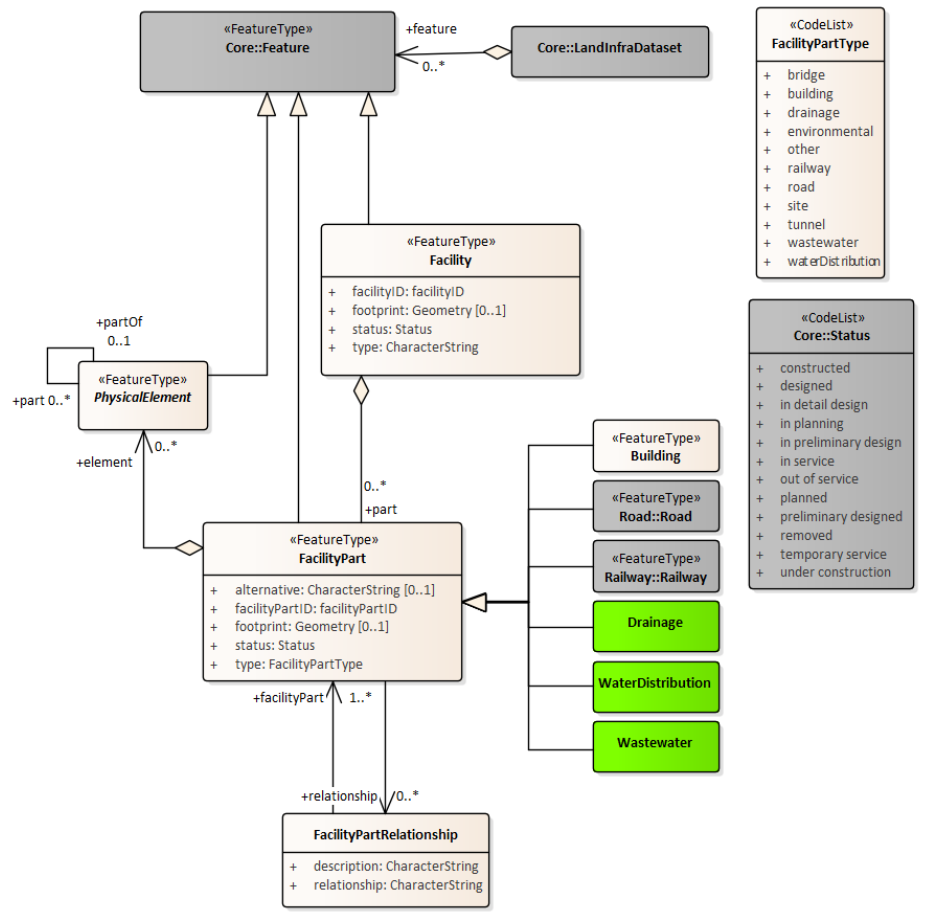

Şekil 11: Landlnfra tesis paketi

Islak altyapı tesisleri olarak belirlenen drenaj, su dağıtım ve atık su tesisleri Tesis paketinde yer almaktadır (OGC, 2017b). Şekil 11, bu pakete ait temel sınıflar ile ilişkilerini göstermektedir. Tesis sınıfı, tesisin tanımlayıcısı, coğrafi sınırları ile mevcut durumunu (örneğin, planlanan, sökülmüş, kullanımda, proje aşamasında vb.) belirten özniteliklerini içerir. Tesisler, ıslak teknik altyapı tesisleri, bina bölümleri, karayolu veya demiryolu gibi temalara ait bir ya da birden fazla bileşenden oluşabilir. Bu bileşenler TesisBileşeni (FacilityPart) sınıfı ve her bir temaya özgü alt sınıflarla temsil edilmektedir. Farklı bileşenler arasındaki ilişkiler TesisBileşenIlişskisi (FacilityPartRelationship) sınıfıyla temsil edilir. FizikselEleman (PhysicalElement) soyut sınıfı, tesis bileşenlerinin birleşerek oluşturduğu fiziksel tesisleri ifade eder. Tesis ve bileşenleri, öz modelde tanımlanan Detay üst sınıfından türetilmiştir; konumsal özellikleri bu sınıftan aktarılan özelliklerle temsil edilir.

Tesis paketinde, tesisler ve onları oluşturan bileşenler ile ilgili genel tanımlamalara yer verilmiştir. Farklı temalara özgü tesisler, diğer paketlerde detaylandırılmıştır. Örneğin, Bina (Building), Bă̆ımsızBölüm (Condominium) paketinde bina bölümlerini içerecek biçimde detaylandırılmaktadır. Karayolu ve demiryolu temalarına özgü tesisler ile tasarımları Yol (Road) ve Demiryolu (Railway) paketlerinde detaylandırılmıştır (Şekil 11). Islak teknik altyapı tesislerine ait sınıfların benzer biçimde modellenerek ayrı uygulama şemalarının/paketlerinin geliştirilmesi planlanmıştır.

\subsection{Yeraltı Veri Tanımlama ve Entegrasyon Modeli (MUDDI)}

2019 yılında, OGC tarafından bir mühendislik raporu kapsamında yayımlanan Yeraltı Veri Tanımlama ve Entegrasyon Modeli (Model for Underground Data Definition and Integration, MUDDI), gömülü teknik altyapı tesislerine ve yeraltı ortamına ilişkin coğrafi verilerin temsiline ve entegre edilmesine olanak veren kavramsal bir veri modelidir (Lieberman, 2019). Teknik altyapı tesislerine ve yeraltı ortamına ilişkin çeşitli amaçlarla geliştirilmiş ve farklı özellikler sunan coğrafi veri modellerini bütünleştirmeyi, böylelikle farklı kaynak, sistem ve şemadaki yeraltı verilerinin birlikte kullanımını sağlamayı amaçlar. Bu doğrultuda, mümkün olduğunca mevcut veya geliştirilmekte olan modellerden (örneğin, INSPIRE/IMKL, CityGML, GeoSciML) yararlanılmış, bunlarla eşleştirilerek ilişkileri ortaya konmuştur. Böylelikle, CityGML Utility Network ADE, INSPIRE, IMKL, GeoSciML gibi modellere uygun biçimde üretilmiş bulunan ayrık veri setlerinin birlikte kullanılarak etkinliklerinin artırılması amaçlanmıştır. Ayrıca, yeraltı altyapı bilgisinin doğrudan 
ölçülebilmesi, sensör bilgileriyle ilişkilendirilebilmesi ve spesifik uygulamaların desteklenmesi için esnek bir yapıda tasarlanmıştır.

Modelin yayımlanan versiyonu, (1) rutin sokak kazıları, (2) büyük ölçekli inşaat projelerinin planlanması, tasarımı ve yapımı ile (3) afet planlama uygulamalarında/kullanım durumlarında yeraltı tesislerine yönelik gereksinim duyulan coğrafi verileri kapsar. Bu uygulamalar birbirlerinden farklı detay düzeyinde coğrafi verilere gereksinim duymaktadır. Modelin farklı kullanım durumlarının/uygulamalarının gerektirdiğinden daha detaylı ve karmaşık olmaması için modüler bir yapı benimsenmiştir. $\mathrm{Bu}$ doğrultuda modelde hem yeraltı ortamına ilişkin hem de gömülü teknik altyapı tesislerinin temel geometrik ve fiziksel özelliklerini içeren bir öz (core) model ve öz modeldeki sınıflarla ile ilişikli, isteğe bağlı olarak etkinleştirilebilen eklenti veya ara yüzler (interface) bulunmaktadır (Şekil 12).

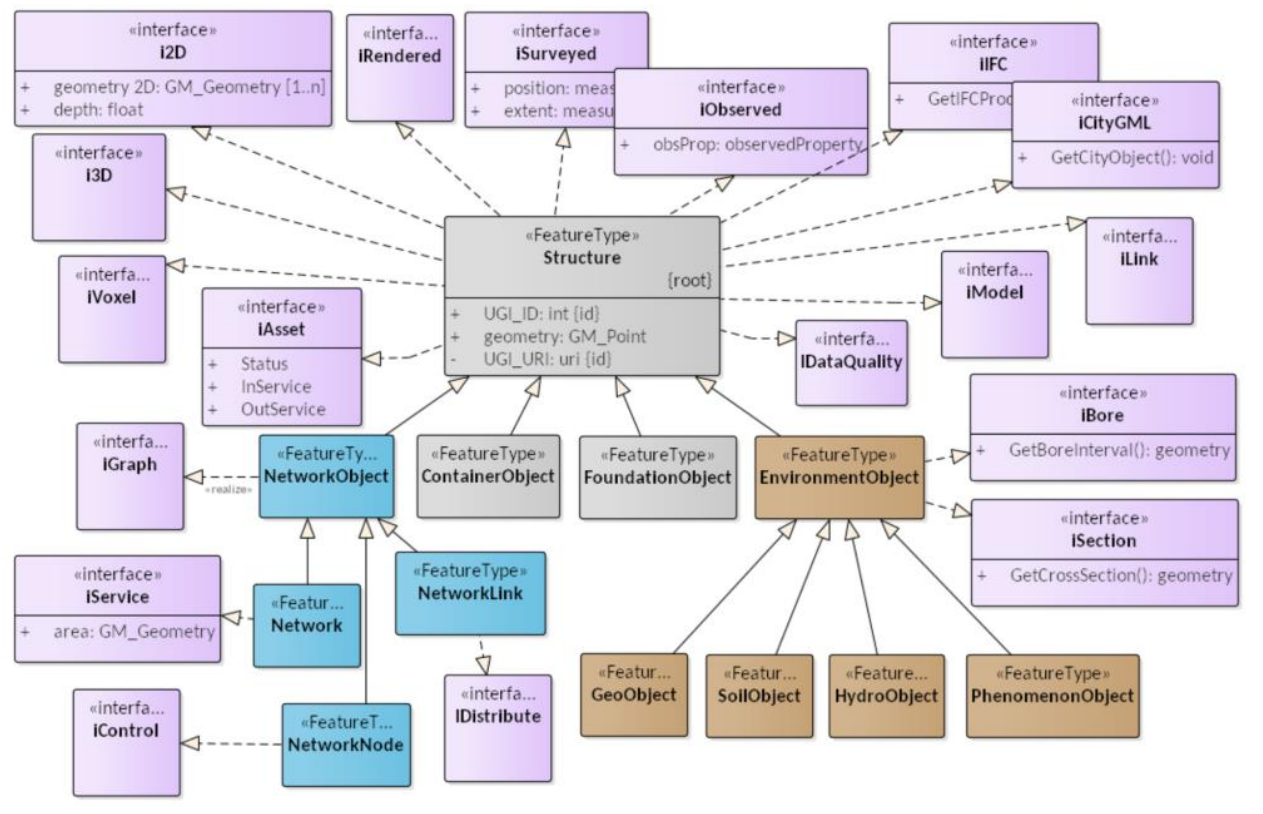

Şekil 12: MUDDI öz modeli ve arayüzler. Eflatun renk arayüzleri, diğer renkler öz modele ait sınıfları göstermektedir (Lieberman, 2019)

Öz modelin olanak verdiğinden daha ayrıntılı geometrik ve işlevsel özelliklere ait bilgilerin bu arayüzler aracılığıyla ifade edilmesi öngörülmüştür. Arayüzler, öz modeldeki sınıflara yeni öznitelikler ve/veya işlemler eklemektedir. Örneğin, nesnelerin detaylı geometrileri I2D, I3D ve/veya IVoxel arayüzleriyle ifade edilmektedir. Çeşitli simülasyonlar için gerekli parametreler, IModel arayüzü ile eklenir. Tesislerin bakımına, konumlarının belirlenmesine ve veri kalitesine yönelik bilgiler, sırasıyla, IAsset, ISurveyed ve IDataQuality arayüzlerinin gerçekleştirilmesiyle ifade edilir. Bu modüler yapı, IFC veya CityGML gibi diğer veri modellerinden kavramların entegre edilmesine olanak verir. ICityGML ve IIFC arayüzlerinde, CityGML ve IFC formatındaki verilerin kullanımı için gereken işlemler (GetCityGML, GetIFC) belirtilmektedir.

Öz model; (1) yeraltına ilişkin yapısal özellikleri, (2) ağ biçiminde temsil edilen teknik altyapı nesnelerini (3) muhafaza elemanlarını, (4) destekleyici elemanları ve (5) yeraltı ortamına ait özellikleri temsil eden beş temel sınıf içermektedir. Yapı (Structure) sınıfı; tanımlayıcı, şekil, renk, malzeme, durum gibi, tüm yeraltı nesnelerine ait ortak özellikleri içermektedir (Şekil 12).

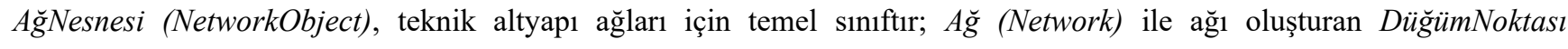
(NetworkNode) ve düğüm noktalarını bağlayan ĂgBă̆lantısı (NetworkLink) nesnelerini temsil eden alt sınıfları içerir. Ağlarda yer alan kontrol ve denetim elemanlarına ilişkin öznitelikler IControl ve IDistribute arayüzlerinin gerçekleştirilmesi 
ile eklenir. Bu öznitelikler, düğüm noktasının kaynak noktası, nihai nokta, açık veya kapalı olma durumu, ya da kenar/hattın akış yönü, hızı vb. olabilir. Bir ağın ya da ağ bileşeninin etkin olduğu bölgeyi temsil etmek için IService arayüzü kullanılmaktadır.

MUDDI modeli, halen Amerika İnşaat Mühendisleri Birliği tarafından geliştirilen ve endüstri standardı olarak yayımlanması beklenen taslak as-built standardında (teknik altyapı verilerinin kaydedilmesi ve değişimi - Recording And Exchanging Utility Infrastructure Data) (ASCE, 2018) belirtilen veri gereksinimlerini karşılayacak biçimde geliştirilmekte ve modele tesislerin ölçme, konum doğruluğu, veri kalitesi, malzeme kapasite gibi özellikleri dahil edilmektedir (Lieberman \& Roensdorf, 2020). MUDDI modelinin güncel versiyonuna GitHub deposundan ${ }^{7}$ erişilebilmektedir.

\section{Değerlendirme}

\subsection{Modellerin İçeriği ve Kapsamı}

$\mathrm{Bu}$ çalışmada incelenen coğrafi veri modelleri farklı kullanım alanlarına yöneliktir. Bu doğrultuda gerçek dünyadaki teknik altyapı tesis ve ağları farklı şekillerde soyutlanmış, modeller farklı bakış açılarıyla tasarlanmıştır. Modellerin tasarım amaçları; içeriklerini, detay düzeylerini ve nesnelerin temsil biçimlerini doğrudan etkilemektedir.

INSPIRE Teknik Altyapı Ağları veri şemasının amacı, farklı kuruluşların yönettiği değişken yapıda ve düzeyde bulunan veri ve veri modellerinin uyumlandırılmasını sağlamak, teknik altyapı kuruluşları arasındaki verinin yeniden kullanımını ve paylaşımını etkinleştirmektir. Bu doğrultuda teknik altyapı tesisleri; elektrik, petrol, gaz ve kimyasallar, su, atık su ve telekomünikasyon gibi sektör türleri esas alınarak ayrı paketlerle temsil edilmiştir.

UNADE, kritik altyapıların karşılıklı bağımlılıklarını kent modelleriyle bütünleşik biçimde temsil eder. Bu nedenle, teknik altyapı hatlarının ilettiği malzeme tiplerini temel alan bir sınıflandırma yaklaşımı benimsenmiştir. Ağlar, INSPIRE modelindeki gibi teknik altyapı sektörlerini esas almaz; aksine aynı tür maddeyi taşıyan teknik altyapı tesislerinin bir ağ oluşturduğu düşünülür. Modelleme yaklaşımı, teknik altyapı tesislerinin fiziksel özellikleri, ilettikleri maddeler ile işlevlerine odaklanırken, sahipleri ve sektörleri ikincil düzeyde önemlidir.

IFC, yapılara ait proje yönetimine odaklanmaktadır; bu nedenle bina içlerinde ve binaların bulundukları arazideki ısıtma, soğutma, havalandırma, sıhhi tesisat, elektrik, elektronik, haberleşme gibi teknik altyapı tesislerini temsil eder.

MUDDI, yer altı teknik altyapı tesislerine ait farklı veri modellerine uygun biçimde üretilmiş veri setlerini bütünleştirerek işlevselliklerini artırmayı hedeflemekte, bu doğrultuda bir çerçeve sunmaktadır. Öz modelde, teknik altyapı tesislerinin temsili için temel özellikler yer almaktadır. Sektörlere özgü modellerin ara yüzler aracıllğııla eklenmesi öngörülmüştür.

LandInfra kavramsal modeli ve InfraGML uygulama şeması, inşaat mühendisliği ve altyapı projeleri ile araziye odaklanmaktadır. Teknik altyapı tesisleriyle ilgili olarak yalnızca ıslak altyapılar olarak tanımlanan, drenaj, su dağıtımı ve atık su altyapı tesislerine ait sınıfları içerir. Ancak bu sınıflar, standardın mevcut versiyonunda detaylandırılmamıştır. Elektrik, telekomünikasyon, doğalgaz gibi teknik altyapı tesislerine ait projeler ile fiziksel bileşenleri kapsam dış1 tutulmuştur.

\footnotetext{
${ }^{7}$ https://github.com/opengeospatial/muddi
} 
Tablo 1: Modellerin geometrik temsillerinin karşılaştırılması

\begin{tabular}{|c|c|c|c|c|c|}
\hline & INSPIRE-UN & $\begin{array}{l}\text { CityGML } \\
\text { UNADE } \\
\end{array}$ & InfraGML & IFC & MUDDI \\
\hline Modelleme amacı & $\begin{array}{l}\text { Çevresel } \\
\text { uygulamalar için } \\
\text { coğrafi veri } \\
\text { değişimi }\end{array}$ & $\begin{array}{l}\text { Kent modelleriyle } \\
\text { entegre biçimde } \\
\text { coğrafi analizler }\end{array}$ & $\begin{array}{c}\text { Mühendislik } \\
\text { altyapılarının } \\
\text { proje, tasarım, } \\
\text { inşa vb. } \\
\text { süreçlerinde veri } \\
\text { değişimi }\end{array}$ & $\begin{array}{l}\text { Mimarlık, inşaat } \\
\text { ve tesis } \\
\text { yönetimine ilişkin } \\
\text { taraflar arasında } \\
\text { veri değişimi }\end{array}$ & $\begin{array}{l}\text { Yeraltı ortamına } \\
\text { ilişkin verilerin } \\
\text { entegrasyonu için } \\
\text { çerçeve sunma }\end{array}$ \\
\hline $\begin{array}{c}\text { Yatay konumsal } \\
\text { kapsam }\end{array}$ & Kent/ülke/bölge & Kent, bina & Kent, bina, bölge & Bina, proje alanı & Kent \\
\hline $\begin{array}{c}\text { Düşey konumsal } \\
\text { kapsam }\end{array}$ & $\begin{array}{c}\text { Yer alt1 ve yer } \\
\text { üstü }\end{array}$ & $\begin{array}{c}\text { Yer alt1 ve yer } \\
\text { üstü }\end{array}$ & $\begin{array}{c}\text { Yer alt1 ve yer } \\
\text { üstü }\end{array}$ & $\begin{array}{c}\text { Yer alt1 ve yer } \\
\text { üstü }\end{array}$ & Yer altı \\
\hline Altyapı tesisleri & $\begin{array}{l}\text { Elektrik, petrol, } \\
\text { gaz, kimyasal, su, } \\
\text { atık su, termal, } \\
\text { elektronik } \\
\text { haberleşme }\end{array}$ & $\begin{array}{l}\text { Kat1, sıv1, gaz, } \\
\text { elektrik, optik }\end{array}$ & $\begin{array}{c}\text { Su, su toplama, } \\
\text { at1k su }\end{array}$ & $\begin{array}{l}\text { Isıtma ve soğutma } \\
\text { havalandırma, } \\
\text { sihhi tesisat, } \\
\text { elektrik, } \\
\text { elektronik } \\
\text { haberleşme }\end{array}$ & - \\
\hline $\begin{array}{c}\text { Farklı veri } \\
\text { setleriyle } \\
\text { entegrasyon }\end{array}$ & - & $\begin{array}{c}\text { Evet, (CityGML } \\
\text { formatında } 3 \\
\text { boyutlu kent } \\
\text { modelleri) }\end{array}$ & $\begin{array}{c}\text { Evet, diğer } \\
\text { mühendislik } \\
\text { yapıları ile } \\
\text { projeleri }\end{array}$ & $\begin{array}{c}\text { Evet, yap1 } \\
\text { elemanları ve } \\
\text { projeleri }\end{array}$ & Evet, yeraltı ortam 1 \\
\hline
\end{tabular}

\subsection{Coğrafi Temsil (Geometri)}

UNADE, MUDDI ve INSPIRE UN modellerinde teknik altyapı ağları, düğüm-kenar-düğüm (node-arc-node) olarak ifade edilen çizge (graph) yapısı ile temsil edilmektedir. Bu yapıda düğümler nokta; kenarlar ise çizgi olarak temsil edilir; bir ağ en az iki düğüm ile bir kenardan oluşur. Çizgi/kenar özelliği gösteren nesneler, kablo, boru gibi doğrusal nesneleridir. Nokta özelliği gösteren nesneler; pompa, sayaç, vana vb. ağ elemanları olabileceği gibi hatların birleşim noktaları, uç noktaları gibi karakteristik noktaları olabilir. Topolojik yapı, birbirlerine fiziksel olarak bağlı teknik altyapı tesisleri arasındaki ilişkiyi modelleyerek, örneğin, teknik altyapı tesislerinin hasar görmesi veya devre dışı kalması durumunda diğer tesislere olan etkilerinin belirlenmesi vb. gibi konumsal analizlerinin yapılmasına olanak verir. MUDDI ile UNADE, INSPIRE-UN modelinden farklı olarak, farklı ağlar arasındaki ilişkileri temsil etmeye olanak vermektedir. IFC modelinde, nesneler arasındaki ilişkiler, IfcRelConnects sınıfının alt tipleri (örneğin, IfcRelConnectsPorts, IfcRelConnectsPortToElement, IfcRelFlowControlElements) ile tanımlanır. Bu ilişkiler, aynı ağa ya da farklı ağlara ait tesisler arasında kurulabilir.

CityGML nesnelerin farklı anlamsal ve geometrik temsil ediliş biçimlerini tanımlayan detay düzeyi (level of detail, LoD) kavramını kullanmaktadır. UNADE modeli de CityGML modelinden türetildiği için bu özelliğe sahiptir ve tesislerin temsili için birden fazla geometri yapısı kullanılabilir. Bununla beraber, anlamsal bakımdan bir detay düzeyi tanımı yapılmamıştır. Farklı kullanım durumlarında geometrik, topografik ve işlevsel bakımdan gereksinim duyulan detay düzeyi tanımlamalarının yapılması planlanmaktadır (Kutzner, Hijazi, \& Kolbe, 2018, s. 30). IFC, tesislerin farklı geometrik yapılarda temsiline olanak vermekte ve kullanıcılar kendi detay düzeyi tanımını yapabilmektedir. IFC'de yer alan LoD (level of development) kavramı, bir projede söz konusu modelin temsil ettiği gelişme düzeyini ifade eder ve bu tanımlama geometrik anlamda bir detay düzeyi değildir. MUDDI, kullanım durumlarının gerektirdiği detay düzeyinde veriyi temsil edebilme hedefi doğrultusunda, modüler ve esnek bir yapıda tasarlanmıştır. INSPIRE-UN ve LandInfra/InfraGML'de detay düzeyine ait tanımlamalar yer almamaktadır.

Teknik altyapı tesislerinin 3 boyutlu geometrilerinin temsili için UNADE ve LandInfra/InfraGML sınır temsili (boundary representation, BRep) tekniğini kullanmaktadır. IFC, sınır temsiline ek olarak yapısal katı geometri (constructive solid geometry, CSG) gibi parametrik modelleri de desteklemektedir. MUDDI öz modeli 3 boyutlu nesnelerin temsilini 
desteklemez ancak $I 3 D$ ve IVoxel arayüzleriyle, katı cisim geometrileri ve voxel koleksiyonlarıyla ifade edilen 3 boyutlu nesnelerin öz model ile birlikte kullanımına olanak verir. Bununla beraber, güncelleştirilmekte olan versiyonu tesislerin uzunluk, derinlik, yükseklik, genişlik vb. ölçülerini içerir ve böylelikle 3 boyutlu görselleştirme için gerekli parametreleri sağlar. 2 boyutlu bir ă̆ modelinden türetilen INSPIRE-UN, tesislerin derinlik/yükseklik bilgisini içermez ve 3 boyutlu temsiline olanak vermez.

Tablo 2: Modellerin içerik ve kapsam açılarında karşılaştırılması

\begin{tabular}{|c|c|c|c|c|c|}
\hline & INSPIRE-UN & $\begin{array}{c}\text { CityGML } \\
\text { UNADE }\end{array}$ & InfraGML & IFC & MUDDI \\
\hline $\begin{array}{c}2 \text { boyutlu ağ } \\
\text { topolojisi }\end{array}$ & + & + & - & + & + \\
\hline $\begin{array}{c}\text { Farklı türdeki } \\
\text { ağlar arasındaki } \\
\text { ilişkiler/bağlılık }\end{array}$ & - & + & - & + & + \\
\hline 3 Boyutlu Temsil & - & + & + & + & + \\
\hline $\begin{array}{c}\text { Farklı detay } \\
\text { düzeyleri }\end{array}$ & - & + & - & + & + \\
\hline
\end{tabular}

\section{Sonuç ve Öneriler}

Teknik altyapı tesislerine ait coğrafi veriler genellikle altyapı sahibi işletmeci kuruluşlar tarafından yönetilmektedir. Ancak bir altyapı tesisinin projelendirilmesi, inşası, bakımı ile kent idaresi, afet yönetimi gibi süreçlerde diğer tüm teknik altyapı tesislerine ait coğrafi verilere gereksinim duyulmaktadır. Bu çalışmada, bu verilerin paylaşımı/değiş̧imi için geliştirilmiş, literatürde kabul görmüş ve standart olarak yayımlanmış veri modelleri incelenmiştir. Bu araştırma sonunda, tüm uygulamalar için kullanılabilecek, uluslararası düzeyde standart olarak kabul edilmiş genel bir coğrafi veri modeli bulunmadığı anlaşılmıştır. INSPIRE-UN, UNADE, IFC ve InfraGML modellerinin, odaklandıkları farklı kullanım durumları ile uygulamaların gereksinimleri doğrultusunda, farklı yeteneklere, geometrik ve anlamsal içeriklere sahip oldukları görülmektedir. Örneğin, INSPIRE-UN, teknik altyapı kazı çalışmalarının koordinasyonunda coğrafi veri değişimi uygulamalarına; UNADE ise kapsamlı ağ temsili ve 3 boyutlu kent modelleriyle entegrasyon sağlaması nedeniyle, şebeke analizlerini ve simülasyonları içeren uygulamalara temel oluşturmuştur. Halen geliştirilmekte olan MUDDI, teknik altyapı verisi gerektiren tüm uygulamalar için bütüncül bir yaklaşım sunmakta ve bir veri setinin birden fazla uygulamada kullanımını etkinleştirmeyi hedeflemektedir.

Kentlerde yer altını yoğun biçimde kullanan teknik altyapı tesislerine ilişkin uygulamalar, çoğunlukla tesislere ait 3 boyutlu coğrafi veri temsilini gerektirir. Bu doğrultuda iki boyutlu ağ modelini temel alan INSPIRE-UN haricindeki diğer coğrafi veri modellerinin bu işlevselliği sağlayacak biçimde tasarlandığı görülmektedir. Bununla beraber, Hollanda ve Fransa'da teknik altyapı kazı çalışmalarında güvenliğin sağlanmasına yönelik ulusal mevzuatı destekleyen IMKL ve Star-DT standart coğrafi veri modelleri, INSPIRE-UN modelinin 3 boyutlu temsile olanak verecek biçimde geliştirilebileceğini göstermiştir. Ülkemizde, teknik altyapı tesislerine yönelik standart bir veri modeli sunan TUCBS Altyapı Ağları uygulama şemasının etkinliği, Hollanda ve Fransa'daki deneyimlerden yararlanarak geliştirilebilir; böylelikle altyapı tesislerinin onarımı veya deplase edilmesi veya yeni tesislerin yapım sürecindeki planlama, projelendirme ve inşaat faaliyetlerinin koordinasyonu sağlanabilir. 


\section{Yazar Katkısı}

Azer İlgar: Fikir, Tasarım, Literatür taraması, Analiz ve yorumlama, Yazım. Volkan Çağdaş: Fikir, Denetleme, Makale değerlendirme.

\section{Çıkar Çatışması Beyanı}

Yazarlar, bu çalışmada bilinen ilgili herhangi bir finansal veya finansal olmayan çıkar çatışması olmadığını beyan eder.

\section{Kaynaklar}

Al-Hader, M., Rodzi, A., Sharif, A. R., \& Ahmad, N. (2009). SOA of smart city geospatial management. Proceedings of the 2009 Third UKSim European Symposium on Computer Modeling and Simulation, 6-10.

ASCE (2018). Standard Guideline for Recording and Exchanging Utility Infrastructure Data White Paper. https://www.asce.org/uploadedFiles/Technical_Areas/Construction_Engeering/Content_Pieces/as-built-standards-whitepaper.pdf (Erişim Tarihi: 20.05.2021).

Beck, A. R., Fu, G., Cohn, A. G., Bennett, B., \& Stell, J. G. (2008). A framework for utility data integration in the UK. Urban and Regional Data Management, 261-276.

Becker, T., Nagel, C., \& Kolbe, T. H. (2011). Integrated 3D modeling of multi-utility networks and their interdependencies for critical infrastructure analysis. T. Kolbe, G. König, \& C. Nagel (ed), Advances in 3D geo-information sciences. Berlin, Heidelberg: Springer.

Becker, T., Bartels, M., Hahne, M., Hempel, L., \& Lieb, R. (2012). Cascading effects and interorganisational crisis management of critical infrastructure operators. Findings of a research project. on Geo-information for Disaster Management-Best Practices, 105.

Becker, T., Nagel, C., \& Kolbe, T. H. (2013). Semantic 3D modeling of multi-utility networks in cities for analysis and 3D visualization. Pouliot, J., Daniel, S., Hubert, F., \& Zamyadi, A. (ed) Progress and New Trends in 3D Geoinformation Sciences. Berlin, Heidelberg: Springer.

Biljecki, F., Kumar, K., \& Nagel, C. (2018). CityGML application domain extension (ADE): overview of developments. Open Geospatial Data, Software and Standards, 3(1), 1-17.

Boates, I., Agugiaro, G., \& Nichersu, A. (2018). Network modelling and semantic 3d city models: testing the maturity of the utility network ADE for CITYGML with a water network test case. ISPRS Annals of Photogrammetry, Remote Sensing \& Spatial Information Sciences, 4(4).

buildingSMART (2018a), Introduction, https://standards.buildingsmart.org/IFC/RELEASE/IFC4/ADD2_TC1/HTML/link/introduction. htm (Erişim Tarihi: 10.05.2021)

buildingSMART (2018b), Resource definition data schemas, https://standards.buildingsmart.org/IFC/RELEASE/IFC4/ADD2_TC1/ HTML/schema/chapter-8.htm (Erişim Tarihi: 10.05.2021)

buildingSMART (2018c), Core data schemas, https://standards.buildingsmart.org/IFC/RELEASE/IFC4/ADD2_TC1/HTML/schema /chapter-5.htm (Erişim Tarihi: 10.05.2021)

buildingSMART (2018d), Shared element data schemas, https://standards.buildingsmart.org/IFC/RELEASE/IFC4/ADD2_TC1/HTML/ schema/chapter-5.htm (Erişim Tarihi: 10.05.2021)

CBSGM (2020). Türkiye Ulusal Coğrafi Bilgi Sistemi Altyapı Teması Veri Tanımlama Dokümanı. https://tucbs-publicapi.csb.gov.tr/tucbs/tucbs_tanimlama_dokumanlari/TUCBS_AY.pdf (Erişim Tarihi: 21.05.2021)

Cheng, J. C., \& Deng, Y. (2015). An integrated BIM-GIS framework for utility information management and analyses. Computing in Civil Engineering 2015, 667-674.

den Duijn, X., Agugiaro, G., \& Zlatanova, S. (2018). Modelling below-and above-ground utility network features with the CityGML Utility Network ADE: Experiences from Rotterdam. Proceedings of the 3rd International Conference on Smart Data and Smart Cities, Delft, The Netherlands, 43-50.

Fossatti, F., Agugiaro, G., olde Scholtenhuis, L., \& Dorée, A. (2020). Data modeling for operation and maintenance of utility networks: 
Implementation and testing. ISPRS Annals of the Photogrammetry, Remote Sensing and Spatial Information Sciences, 6(4/W1), 69-76. Gale, W., \& Hammerschmidt, A. (2015). Innovation in Technologies to Support the Storage, Retrieval, and Use of 3-D Utility Location Data in Highway Renewal: Transportation Research Board of the National Academies.

Geonovum. (2015), IMKL2015 - Dataspecificatie Utiliteitsnetten https://register.geostandaarden.nl/informatiemodel/imkl2015/1.0.0RC1/ IMKL2015_Dataspecificatie_1.0RC1.pdf (Erişim Tarihi: 20.05.2021)

Gilbert, T., Barr, S., James, P., Morley, J., \& Ji, Q. (2018). Software systems approach to multi-scale GIS-BIM utility infrastructure network integration and resource flow simulation. ISPRS International Journal of Geo-Information, 7(8), 310.

Hijazi, I., Ehlers, M., Zlatanova, S., \& Isikdag, U. (2009). IFC to CityGML transformation framework for geo-analysis: a water utility network case. 4th International Workshop on 3D Geo-Information.

Hijazi, I., Ehlers, M., Zlatanova, S., Becker, T., \& Berlo, L. v. (2011). Initial investigations for modeling interior Utilities within $3 D$ Geo Context: Transforming IFC- interior utility to CityGML/UtilityNetworkADE. T. H. Kolbe, G. König, \& C. Nagel (ed) Advances in 3D Geo-Information Sciences. Lecture Notes in Geoinformation and Cartography. Berlin, Heidelberg: Springer.

Hijazi, I. H., Ehlers, M., \& Zlatanova, S. (2012). NIBU: A new approach to representing and analysing interior utility networks within 3D geo-information systems. International Journal of Digital Earth, 5(1), 22-42.

INSPIRE (2013). D2.8.III.6 Data Specification on Utility and Government Services Technical Guidelines.

Islam, T., \& Moselhi, O. (2012). Modeling geospatial interdependence for integrated municipal infrastructure. Journal of Infrastructure Systems, 18(2), 68-74.

Jung, Y. J. (2012). Evaluation of subsurface utility engineering for highway projects: Benefit-cost analysis. Tunnelling and underground space technology, 27(1), 111-122.

Kolbe, T. H. (2009). Representing and exchanging 3D city models with CityGML. T. H. Kolbe, G. König, \& C. Nagel (ed) Advances in 3D Geo-Information Sciences. Lecture Notes in Geoinformation and Cartography. Berlin, Heidelberg: Springer.

Kutzner, T., \& Kolbe, T. H. (2016). Extending semantic 3D city models by supply and disposal networks for analysing the urban supply situation. Lösungen für eine Welt im Wandel, Dreiländertagung der SGPF, DGPF und OVG, 36. Wissenschaftlich-Technische Jahrestagung der DGPF, pp. 382-394.

Kutzner, T., Hijazi, I., \& Kolbe, T. H. (2018). Semantic modelling of 3D multi-utility networks for urban analyses and simulations: The CityGML utility network ADE. International Journal of 3-D Information Modeling (IJ3DIM), 7(2), 1-34.

Kutzner, T., Chaturvedi, K., \& Kolbe, T. H. (2020). CityGML 3.0: New functions open up new applications. PFG-Journal of Photogrammetry, Remote Sensing and Geoinformation Science, 88(1), 43-61.

Lee, P. C., Wang, Y., Lo, T. P., \& Long, D. (2018). An integrated system framework of building information modelling and geographical information system for utility tunnel maintenance management. Tunnelling and Underground Space Technology, 79, $263-273$.

Lieberman, J., \& Ryan, A. (2017). OGC Underground Infrastructure Concept Study Engineering Report: Open Geospatial Consortium.

Lieberman, J. (2019). Model for Underground Data Definition and Integration (MUDDI) Engineering Report: Open Geospatial Consortium.

Lieberman, J., \& Roensdorf, C. (2020). Modular Approach to 3D Representation of Underground Infrastructure in the Model for Underground Data Definition and Integration (MUDDI). The International Archives of Photogrammetry, Remote Sensing and Spatial Information Sciences, 44, 75-81.

Marzouk, M., \& Othman, A. (2020). Planning utility infrastructure requirements for smart cities using the integration between BIM and GIS. Sustainable Cities and Society, 57, 102120.

OGC (2016). P. Scarponcini (ed) OGC Land and Infrastructure Conceptual Model Standard (LandInfra).

OGC (2017a). P. Scarponcini (ed) OGC InfraGML 1.0: Part 0 - LandInfra Core - Encoding Standard. P.

OGC (2017b). P. Scarponcini (ed) OGC InfraGML 1.0: Part 2 - LandInfra Facilities and Projects - Encoding Standard. P.

olde Scholtenhuis, L. L., Hartmann, T., \& Dorée, A. G. (2016). 4D CAD based method for supporting coordination of urban subsurface utility projects. Automation in construction, 62, 66-77.

olde Scholtenhuis, L. L., den Duijn, X., \& Zlatanova, S. (2018). Representing geographical uncertainties of utility location data in 3D. Automation in construction, 96, 483-493.

Ribberink, O. (2017). Standardization of geo data exchange between network operators and contractors in underground utilities (Yüksek Lisans Tezi). Geographical Information Management and Applications (GIMA), Hollanda. 
Rinaldi, S. M., Peerenboom, J. P., \& Kelly, T. K. (2001). Identifying, understanding, and analyzing critical infrastructure interdependencies. IEEE control systems magazine, 21(6), 11-25.

Sterling, R. L., Anspach, J. H., Allouche, E. N., Simicevic, J., Rogers, C. D., Weston, K. E., \& Hayes, K. (2009). Encouraging innovation in locating and characterizing underground utilities (No. SHRP 2 Report S2-R01-RW).

Talmaki, S., Kamat, V. R., \& Cai, H. (2013). Geometric modeling of geospatial data for visualization-assisted excavation. Advanced Engineering Informatics, 27(2), 283-298.

van den Brink, L., Stoter, J., \& Zlatanova, S. (2013). UML-based approach to developing a CityGML application domain extension. Transactions in GIS, 17(6), 920-942.

van den Brink, L., Janssen, P., \& Quak, W. (2017). IMKL2015 - Dataspecificatie Utiliteitsnetten. Geonovum. https://register.geostandaard en.nl/informatiemodel/imk12015/1.2.1/IMKL2015_Dataspecificatie_1.2.1.pdf (Erişim Tarihi: 15.01.2021)

Vishnu, E., \& Saran, S. (2018). SEMANTIC MODELING OF UTILITY NETWORKS IMPLEMENTATION OF USE CASES FOR DEHRADUN CITY. International Archives of the Photogrammetry, Remote Sensing \& Spatial Information Sciences, XLII-5, 139145.

Wang, M., Deng, Y., Won, J., \& Cheng, J. C. (2019). An integrated underground utility management and decision support based on BIM and GIS. Automation in Construction, 107, 102931.

Yang, Y., Ng, S. T., Xu, F. J., \& Skitmore, M. (2018). Towards sustainable and resilient high density cities through better integration of infrastructure networks. Sustainable Cities and Society, 42, 407-422.

Yao, Z., Nagel, C., Kunde, F., Hudra, G., Willkomm, P., Donaubauer, A., Adolphi, T., \& Kolbe, T. H. (2018). 3DCityDB-a 3D geodatabase solution for the management, analysis, and visualization of semantic 3D city models based on CityGML. Open Geospatial Data, Software and Standards, 3(1), 1-26.

Zhao, L., Liu, Z., \& Mbachu, J. (2019). An integrated BIM-GIS method for planning of water distribution system. ISPRS International Journal of Geo-Information, 8(8), 331. 